\title{
Structure of the cell envelope of corynebacteria: importance of the non- covalently bound lipids in the formation of the cell wall permeability barrier and fracture plane
}

\author{
Virginie Puech, ${ }^{1}$ Mohamed Chami, ${ }^{2,5}$ Anne Lemassu, ${ }^{1}$ \\ Marie-Antoinette Lanéelle, ${ }^{1}$ Bettina Schiffler, ${ }^{3}$ Pierre Gounon, ${ }^{4}$ \\ Nicolas Bayan, ${ }^{2}$ Roland Benz ${ }^{3}$ and Mamadou Daffé ${ }^{1}$
}

Author for correspondence: M. Daffé. Tel: +33 561175 569. Fax: +33 561175994. e-mail: daffe@ipbs.fr

1 Institut de Pharmacologie et Biologie Structurale, Centre National de la Recherche

Scientifique/Université Paul Sabatier (UMR 5089), 205 route de Narbonne, 31077 Toulouse Cedex 04, France

2 Laboratoire des Biomembranes, UMR 8619 CNRS-Université Paris-Sud, 91405 Orsay Cedex, France

3 Lehrstuhl für Biotechnologie, Biozentrum der Universität Würzburg, Am Hubland, D-97074 Würzburg, Germany

4 Institut Pasteur, Service de Microscopie électronique, 25 rue du Docteur Roux, 75724 Paris Cedex 15, France

5 Centre de Génétique Moléculaire, CNRS, 91190 Gif-sur-Yvette, France
With the recent success of the heterologous expression of mycobacterial antigens in corynebacteria, in addition to the importance of these bacteria in biotechnology and medicine, a better understanding of the structure of their cell envelopes was needed. A combination of molecular compositional analysis, ultrastructural appearance and freeze-etch electron microscopy study was used to arrive at a chemical model, unique to corynebacteria but consistent with their phylogenetic relatedness to mycobacteria and other members of the distinctive suprageneric actinomycete taxon. Transmission electron microscopy and chemical analyses showed that the cell envelopes of the representative strains of corynebacteria examined consisted of (i) an outer layer composed of polysaccharides (primarily a high-molecular-mass glucan and arabinomannans), proteins, which include the mycoloyltransferase PS1, and lipids; (ii) a cell wall glycan core of peptidoglycan-arabinogalactan which may contain other sugar residues and was usually esterified by corynomycolic acids; and (iii) a typical plasma membrane bilayer. Freeze-etch electron microscopy showed that most corynomycolate-containing strains exhibited a main fracture plane in their cell wall and contained low-molecular-mass porins, while the fracture occurred within the plasma membrane of strains devoid of both corynomycolate and pore-forming proteins. Importantly, in most strains, the amount of cell wall-linked corynomycolates was not sufficient to cover the bacterial surface; interestingly, the occurrence of a cell wall fracture plane correlated with the amount of non-covalently bound lipids of the strains. Furthermore, these lipids were shown to spontaneously form liposomes, indicating that they may participate in a bilayer structure. Altogether, the data suggested that the cell wall permeability barrier in corynebacteria involved both covalently linked corynomycolates and non-covalently bound lipids of their cell envelopes.

Keywords : cell wall, corynebacteria, mycolic acid, polysaccharide, porin

\section{INTRODUCTION}

Corynebacteria are widely distributed in nature and are important in several ways; apart from the human pathogens, e.g. Corynebacterium diphtheriae, serious economic losses are caused by corynebacterial diseases of animals (Coyle \& Lipsky, 1990; Funke et al., 1997). In addition, some corynebacteria are of considerable economic benefit, for instance in the industrial production of amino acids (Krämer, 1994). They belong to a distinctive suprageneric actinomycete taxon, which also includes mycobacteria, nocardiae, rhodococci and closely related 
genera; all these bacteria share with corynebacteria the property of having an unusual cell envelope composition and architecture, compared to those of other Grampositive micro-organisms. Based on most recently published data, the envelope layers of mycobacteria consist of a typical plasma membrane of phospholipid and protein, a characteristic wall of unusual structure and a complex outer layer (Daffé \& Draper, 1998). Although detailed studies have not been carried out on the cell envelopes of corynebacteria and closely related genera, it is evident from published data that these are very similar to that of mycobacteria, specially in terms of ultrastructure and cell wall chemical composition (Barksdale, 1970; Marienfeld et al., 1997; Sutcliffe, 1997).

The chemical structure of the cell wall skeleton of corynebacteria, mycobacteria and related genera has been extensively studied (for reviews see Daffé \& Draper, 1998; Minnikin \& Goodfellow, 1980; Minnikin \& O'Donnell, 1984; Minnikin et al., 1978; Sutcliffe, 1997); this is formed by a thick meso-diaminopimelic acid-containing peptidoglycan covalently linked to arabinogalactan, which in turn is esterified by longchain $\alpha$-alkyl, $\beta$-hydroxy fatty acids. While these fatty acids in mycobacteria, called eumycolic acids, possess a very long chain $\left(\mathrm{C}_{60-90}\right)$ and may contain various oxygen functions in addition to the $\beta$-hydroxyl group (Daffé $\&$ Draper, 1998), mycolic acids found in other actinomycetes consist of homologous mixtures of saturated and unsaturated acids and contain shorter chains, e.g. $\mathrm{C}_{40-50}$ in nocardomycolic acids and $\mathrm{C}_{22-36}$ in corynomycolic acids (Collins et al., 1982; Minnikin \& Goodfellow, 1980; Minnikin \& O’Donnell, 1984; Minnikin et al., 1978). Although they are Gram-positive bacteria, corynebacteria, mycobacteria and closely related micro-organisms share with Gram-negative bacteria the property of forming in their envelope an outer barrier that is distinct from the plasma membrane. While this additional barrier in Gram-negative microorganisms is a typical bilayer of phospholipid and lipopolysaccharide, in mycobacte9ria and corynebacteria the cell-wall-linked mycolates and corynomycolates certainly participate in this barrier since the disruption of genes that code for mycoloyltransferases, the antigen85 complex and PS1, respectively, causes a decrease in the amount of cell wall-bound mycolates and affects the permeability of the envelope of the mutants (Jackson et al., 1999; Puech et al., 2000). Evidence has also been presented that the chemical structure of mycolic acids plays a role in determining the fluidity and permeability of the mycobacterial cell wall (George et al., 1995; Liu et al., 1996; Dubnau et al., 2000). The existence in mycobacteria, corynebacteria and related genera of an outer membrane diffusion barrier is reinforced by the characterization of cell envelope proteins with poreforming ability (Kartmann et al., 1999; Lichtinger et al., 1998, 1999; Rieß et al., 1998; Mukhopadhyay et al., 1997; Trias et al., 1992; Trias \& Benz, 1994; Senaratne et al., 1998).
In all currently proposed models (Minnikin 1982; Rastogi, 1991; Liu et al., 1995) the outer permeability barrier of mycobacteria consists of a monolayer of mycoloyl residues covalently linked to the cell wall arabinogalactan and includes other lipids which are probably arranged to form a bilayer with the mycoloyl residues. Although no sign of a second lipid bilayer has ever been reported in thin sections of mycobacterial cells (Draper, 1998), freeze-fractured samples of mycobacteria, corynebacteria and related genera (Barksdale \& Kim, 1977; Benedetti et al., 1984; Chami et al., 1995; Takeo et al., 1984) showed that these organisms had two such planes of weakness in their envelopes, in addition to the expected plasma membrane fracture. A second fracture plane, close to the cell surface of mycobacteria, was observed. The existence of distinct lipid domains in the mycobacterial cell envelope has been indicated by studies using progressive erosion of the envelope (Ortalo-Magné et al., 1996) or selective lipophilic probes (Christensen et al., 1999). Freezefracture electron microscopy also showed the presence of ordered arrays on the surface of Corynebacterium glutamicum and other Corynebacterium spp. (Chami et al., 1995; Peyret et al., 1993; Soual-Hoebeke et al., 1999); these surface layer proteins (S-layer) have been shown to be composed of the major corynebacteriasecreted protein, PS2 (Chami et al., 1995; Peyret et al., 1993; Soual-Hoebeke et al., 1999). Such crystalline structures are not visible in published freeze-fractured micrographs of mycobacteria despite a singular report of a crystalline protein layer on the outside of Mycobacterium bovis BCG (Lounatmaa \& Brander, 1989).

From recent advances in molecular biology, it appears that corynebacteria represent a model suitable for functional studies of expression of mycobacterial genes, primarily because (i) they possess the simplest cell wall structure, but one that is functionally and structurally close to those of mycobacteria and related genera; (ii) they are rapid growers and do not form clumps; and (iii) heterologous expression of mycobacterial antigens in $C$. glutamicum has proved to be effective (Salim et al., 1997; Puech et al., 2000). However, it has to be remembered that, unlike the other related microorganisms, corynebacteria are widely used in biotechnology for the production of amino acids (Krämer, 1994); this singular property of corynebacteria suggests that, despite the global similarity of their cell envelope composition with those of related genera, they differ from them in the arrangement of its constituents. To gain further insights into the cell envelope structure of corynebacteria, various representative corynebacterial strains were examined in the present study by combining biochemical analyses and electron microscopy studies. These included the Corynebacterium genus type species C. diphtheriae, the amino-acid-producing strain C. glutamicum, corynomycolate-less strains, i.e. C. amycolatum (Collins et al., 1988; Barreau et al., 1993) and defined corynebacterial cell wall mutants (Chami et al., 1995; Peyret et al., 1993; Joliff et al., 1992; Puech et al., 2000). 


\section{METHODS}

Strains and growth conditions. The strains used were Corynebacterium amycolatum ATCC $49368^{\mathrm{T}}$ and other corynebacterial strains reclassified in this species (Barreau et al., 1993), i.e. CIP (Collection Institut Pasteur) 79.37, CIP 100836, CIP 103818, CIP 103819, CIP 103820 and CIP 103821; C. diphtheriae strain $\mathrm{C}_{\mathrm{r}}(-)$ Tox (Barksdale, 1959); C. glutamicum CGL2005, its isogenic csp1-inactivated mutant CGL2022 (Puech et al., 2000), cspB-disrupted mutant CGL2025 (Peyret et al., 1993), and CGL1009; C. pseudodiphtheriticum (formerly C. hofmanii) strain Breuillaud (Welby-Gieusse et al., 1970); and C. xerosis ATCC $373^{\mathrm{T}}$, ATCC 7094, ATCC 7711 and ATCC 9016. All these strains were routinely grown at $30^{\circ} \mathrm{C}$ with shaking (200 r.p.m.) for $24 \mathrm{~h}$ in $\mathrm{BHI}$ ( $3.7 \%$ Difco brain-heart infusion). For electron microscopy analysis, strains of C. xerosis were also grown for 16, 24, or $48 \mathrm{~h}$ in BHI, and C. glutamicum CGL2005 and its isogenic cspB-disrupted mutant CGL2025 were grown on BHI-containing agar $\left(15 \mathrm{~g} \mathrm{l}^{-1}\right)$ plates. For the structural analysis of polysaccharides, strains were grown on a corynebacterial minimal medium (Huchenq et al., 1984) to avoid possible contamination with polysaccharides originating from the BHI medium.

Isolation of extracellular materials. Bacteria were grown for $48 \mathrm{~h}$ on minimal medium and the culture filtrates were recovered by centrifugation, filtered through a $0 \cdot 2 \mu \mathrm{m}$ sterile filter (Nalgene) and concentrated under vacuum to $1 / 10$ of the original volume; the corresponding cells were dried and weighed. Chloroform and methanol were added to a portion of the filtrates to isolate pids as described below and cold ethanol (6 vols) was added to the remaining portion; after centrifugation of the ethanol precipitates, the pellets were extensively dialysed against distilled water and extracellular materials were obtained and analysed for carbohydrate and protein content as described by Lemassu \& Daffé (1994).

Isolation of the crude surface-exposed materials. Cells grown in either BHI or minimal medium were harvested by centrifugation, extensively washed and gently shaken for 1 min with $10 \mathrm{~g}$ glass beads (4 mm diameter) per $2 \mathrm{~g}$ of wet cells (OrtaloMagné et al., 1995). The resulting material was then suspended in distilled water and immediately filtered through a $0.2 \mu \mathrm{m}$ sterile filter (Nalgene) and concentrated under vacuum to $1 / 10$ of the original volume. Cold ethanol (6 vols) was added to a portion of the crude surface-exposed material, and the ethanol-precipitates were extensively dialysed against distilled water, lyophilized, and analysed for their carbohydrate and protein compositions.

$\mathrm{CHCl}_{3}$ and $\mathrm{CH}_{3} \mathrm{OH}$ were added to the remaining filtrate to give a final one-phase mixture of $\mathrm{H}_{2} \mathrm{O} / \mathrm{CHCl}_{3} / \mathrm{CH}_{3} \mathrm{OH}$ $(0 \cdot 8: 1: 2$, by vol.; Bligh \& Dyer, 1959) and lipids were extracted for $1 \mathrm{~h}$ at room temperature; a two-phase partition mixture was obtained by adding 1 vol. $\mathrm{CHCl}_{3} / \mathrm{H}_{2} \mathrm{O}(1: 1, \mathrm{v} / \mathrm{v})$ to the one-phase solution and lipids were recovered in the lower organic phase, dried and analysed by thin-layer chromatography (TLC) as described below.

Isolation, fractionation and analysis of whole-cell lipids. Lipids were obtained and analysed as previously described (Puech et al., 2000). Briefly, lipids were extracted from wet cells for $16 \mathrm{~h}$ with $\mathrm{CHCl}_{3} / \mathrm{CH}_{3} \mathrm{OH}(1: 1, \mathrm{v} / \mathrm{v})$ at room temperature with continuous stirring; the bacterial residues were re-extracted three times with $\mathrm{CHCl}_{3} / \mathrm{CH}_{3} \mathrm{OH}(2: 1, \mathrm{v} / \mathrm{v})$ and the organic phases were pooled and concentrated. The crude lipid extracts were partitioned between the aqueous and the organic phases arising from a mixture of $\mathrm{CHCl}_{3}$ /
$\mathrm{CH}_{3} \mathrm{OH} / \mathrm{H}_{2} \mathrm{O}(8: 4: 2$, by vol.); the lower organic phases were collected, evaporated to dryness to yield the crude lipid extracts from each strain and comparatively examined by TLC on silica gel-coated plates (G-60, $0.25 \mathrm{~mm}$ thickness, Merck) developed with $\mathrm{CHCl}_{3} / \mathrm{CH}_{3} \mathrm{OH}(9: 1, \mathrm{v} / \mathrm{v})$ or $\mathrm{CHCl}_{3}$ / $\mathrm{CH}_{3} \mathrm{OH} / \mathrm{H}_{2} \mathrm{O}(30: 8: 1$ or $65: 25: 4$, by vol.). Detection of all classes of lipids was performed by spraying the TLC plates with either rhodamine $\mathrm{B}$ or $20 \% \mathrm{H}_{2} \mathrm{SO}_{4}$ in water, the latter followed by heating at $110{ }^{\circ} \mathrm{C}$; glycolipids were revealed by spraying plates with $0.2 \%$ anthrone $(\mathrm{w} / \mathrm{v})$ in concentrated $\mathrm{H}_{2} \mathrm{SO}_{4}$, followed by heating at $110^{\circ} \mathrm{C}$. The Dittmer-Lester reagent (Dittmer \& Lester, 1964) was used for visualizing phosphorus-containing lipids.

In a parallel experiment, surface-exposed lipids were isolated from C. glutamicum cells by extracting bacterial cells with octylglucoside. Briefly, C. glutamicum CGL2005 cells were grown overnight in BHI-rich medium. After extensive washing (twice the culture volume), cells were incubated for $1 \mathrm{~h}$ in $25 \mathrm{mM}$ Tris/ $\mathrm{HCl}$, pH 6.8 buffer containing $1 \%$ octylglucoside. The crude detergent extract was recovered by centrifugation at 8000 r.p.m. for $15 \mathrm{~min}$, extensively dialysed for $24 \mathrm{~h}$ against $25 \mathrm{mM}$ Tris $/ \mathrm{HCl}$, pH 6.8 buffer, and then centrifuged at $200000 \mathrm{~g}$ for $30 \mathrm{~min}$; the pellet was analysed by freeze-fracture electron microscopy.

Quantification of corynomycolic acids was performed as follows. Delipidated cells (1.5 g dry weight) and lipid extracts $(100 \mathrm{mg})$ of the various strains were dried under vacuum prior to weighing and were saponified (Daffé et al., 1983). The saponified products were acidified with $20 \% \mathrm{H}_{2} \mathrm{SO}_{4}$ and the resulting fatty acids were extracted with diethyl ether, converted to methyl esters with diazomethane and dried under vacuum, dissolved in petroleum ether and applied to a Florisil (60-100 mesh, Merck) column equilibrated in petroleum ether. The column was irrigated stepwise with increasing concentrations of diethyl ether in petroleum ether. Fractionations were monitored by TLC on silica gel-coated plates using dichloromethane and fractions containing the same lipid compounds (non-hydroxylated fatty acid methyl esters or corynomycolates) were pooled and weighed. Three sequential determinations from separate preparations of delipidated cells were performed (Puech et al., 2000).

Fatty acid methyl esters from bacteria, delipidated cells and extractable lipids (1-2 mg) were treated with trimethylsilyl reagents (Sweeley et al., 1963) to derivatize hydroxylated components of the mixtures, i.e. corynomycolates, and analysed by GC. The detector response for the various classes of fatty acid methyl esters was determined using authentic samples of $\mathrm{C}_{16: 0}$ and $\mathrm{C}_{32: 0}$ corynomycolate methyl esters. Identification of non-hydroxylated fatty acid methyl esters and corynomycolate derivatives was achieved by gas chromatograph-mass spectrometry (GC-MS).

Production of cell wall, plasma membrane and cytosol fractions. The cell fractions of the various corynebacteria were produced as previously described for mycobacteria (Daffé et al., 1990; Raynaud et al., 1998). Wet cells (5 g) were suspended in $20 \mathrm{ml}$ phosphate buffer $(50 \mathrm{mM}, \mathrm{pH} 7 \cdot 5)$ and the resulting bacterial suspension was passed through a cell disrupter and then centrifuged at 3000 r.p.m. for $15 \mathrm{~min}$ to eliminate unbroken cells; cell walls were recovered from the supernatant by recentrifugation at $10000 \mathrm{~g}$ for $1 \mathrm{~h}$. The resulting pellet was extracted with aqueous $2 \%$ SDS at $95^{\circ} \mathrm{C}$ for $1 \mathrm{~h}$ to remove soluble proteins and finally pelleted at $10000 \mathrm{~g}$; the cell walls were washed three times with $80 \%$ acetone to remove SDS and lyophilized (Daffé et al., 1990). The $10000 \mathrm{~g}$ supernatant was recentrifuged at $100000 \mathrm{~g}$ for 
$2 \mathrm{~h}$ to yield the membrane fraction in the pellet; the supernatant was considered as the cytosol (Raynaud et al., 1998).

Analysis of the cell wall arabinogalactans. O-Methylation of cell wall arabinogalactan was performed by suspending lyophilized walls $(5 \mathrm{mg})$ in $3 \mathrm{ml}$ of dimethylsulphoxide; $300 \mu \mathrm{l}$ of dimethylsulphinyl carbanion was added and the mixture was stirred for $5 \mathrm{~h}$. $\mathrm{CH}_{3} \mathrm{I}$ was slowly added and the suspension was stirred for $2 \mathrm{~h}$. A mixture of $\mathrm{CH}_{3} \mathrm{OH} / \mathrm{H}_{2} \mathrm{O}(1: 1, \mathrm{v} / \mathrm{v})$ was added and the reaction mixture was dialysed against water. The addition of dimethylsulphoxide, dimethylsulphinyl carbanion and $\mathrm{CH}_{3} \mathrm{I}$, followed by dialysis, was repeated four times. The retentate was lyophilized and the per-O-methylated arabinogalactan was hydrolysed with $2 \mathrm{M} \mathrm{CF} \mathrm{CFOH}_{3} \mathrm{CO}$ $110^{\circ} \mathrm{C}$ for $2 \mathrm{~h}$. The hydrolysed products were reduced by $\mathrm{NaBH}_{4}$, acetylated and the resulting partially $\mathrm{O}$-methylated, partially $\mathrm{O}$-acetylated alditols were analysed by GC-MS (Daffé et al., 1990).

Production and analysis of lipoarabinomannans and lipomannan. Delipidated cells (7 g) were extracted with $100 \mathrm{ml}$ ethanol/water $(1 / 1, \mathrm{v} / \mathrm{v})$ for $2 \mathrm{~h}$ at $70^{\circ} \mathrm{C}$; the bacterial residues were recovered by filtration and re-extracted with the same solvent mixture. The two extracts were pooled and dried; then, $100 \mathrm{ml}$ hot phenol/water $(1 / 1, \mathrm{v} / \mathrm{v})$ was added and the mixture was heated for 5 min under continuous stirring followed by partitioning of the two phases. The phenol phase was discarded and the upper phase was extensively washed and dried. The extract was solubilized in water and Triton-X114 $(2 \% \mathrm{w} / \mathrm{v})$ was added to the cooled suspension; the mixture was stirred for $5 \mathrm{~min}$ and then heated at $50{ }^{\circ} \mathrm{C}$ until two phases had formed. The detergent phase was recovered, diluted by adding $2 \mathrm{ml}$ water and washed three times with $\mathrm{CHCl}_{3}$. The resulting aqueous phase was concentrated to a final volume of $0.5 \mathrm{ml}$ and the macromolecules were precipitated with 6 vols cold ethanol. The precipitate was recovered, resuspended in water $(0.5 \mathrm{ml})$ and the macromolecules were reprecipitated with 6 vols cold ethanol. The resulting pellet was dissolved in $100 \mathrm{mM}$ sodium acetate buffer ( $\mathrm{pH} 4.7)$, containing $15 \%(\mathrm{w} / \mathrm{w}$ ) propan-1-ol and fractionated by hydrophobic interaction chromatography (Leopold \& Fisher, 1993) by loading the material onto a column of octyl-Sepharose CL-4B (Pharmacia LKB) equilibrated with the buffer; the column was first irrigated with this buffer and then with the buffer containing 20,30, 40, 50 and $60 \%(\mathrm{v} / \mathrm{v}) n$-propanol. Fractions were collected in bulk, dialysed and monitored for carbohydrate; a portion of each dialysate was analysed for its carbohydrate and lipid compositions. The remaining portion was analysed by SDS-PAGE; authentic samples of mycobacterial lipoarabinomannan and lipomannan from Mycobacterium bovis BCG, kindly provided by T. Brando (IPBS, Toulouse, France) were used as standard.

Preparation of proteins for SDS-PAGE and Western blot analysis. Cell wall proteins from the various strains were released by incubating the cell pellet with $2 \%(\mathrm{w} / \mathrm{v})$ SDS in $50 \mathrm{mM}$ Tris $/ \mathrm{HCl}(\mathrm{pH} 6.8)$ at $100^{\circ} \mathrm{C}$ for $2 \mathrm{~min}(50 \mu \mathrm{l}$ buffer per equivalent of $0.4 \mathrm{ml}$ bacterial suspension at $\left.\mathrm{OD}_{650} 1.2\right)$; the suspension was centrifuged at $12000 \mathrm{~g}$ for $3 \mathrm{~min}$ and the supernatant, which contains only cell wall-associated proteins and not cytoplasmic proteins (Peyret et al., 1993), was collected. Cell wall proteins from roughly $0.4 \mathrm{ml}$ bacterial suspension at $\mathrm{OD}_{650} 1$, were analysed by SDS-PAGE. The pore-forming proteins were isolated from the culture filtrates and different cell fractions as previously described (Lichtinger et al., 1998). Proteins were separated by SDS-PAGE (Laemmli, 1970 ) with a $4 \%$ stacking gel and a $7 \%$ or a $10 \%$ running gel.
Samples were denatured in the presence of $2 \%$ SDS in $50 \mathrm{mM}$ Tris $/ \mathrm{HCl}$ ( $\mathrm{pH} \mathrm{6.8).} \mathrm{After} \mathrm{electrophoresis,} \mathrm{gels} \mathrm{were} \mathrm{either}$ stained with Coomassie brillant blue R-250 or blotted onto nitrocellulose membrane (Towbin et al., 1979). In this latter case proteins were probed with rabbit polyclonal antibodies anti-PS1 (Joliff et al., 1992), anti-PS2 (Peyret et al., 1993), or anti-C. glutamicum porin (Lichtinger et al., 1998). Bands were detected using alkaline-phosphatase-conjugated antibodies and nitroblue tetrazolium (NBT)/5-bromo-4-chloro-3-indoxyl phosphate (BCIP) p-toluidine (Promega) as substates.

Sugar compositional analysis. The sugar constituents of the various materials were determined after acid hydrolysis either with $2 \mathrm{M} \mathrm{CF}_{3} \mathrm{COOH}$ at $110{ }^{\circ} \mathrm{C}$ for $2 \mathrm{~h}$ or with $1 \mathrm{M}$ methanolic $\mathrm{HCl}$ at $80^{\circ} \mathrm{C}$ for $16 \mathrm{~h}$; the mixture of hydrolysed products was dried, treated with trimethylsilyl reagents (Sweeley et al., 1963) to derivatize monosaccharides and analysed by GC for their sugar.

Gas chromatography and mass spectrometry. GC was performed using a Hewlett Packard HP4890A equipped with a fused silica capillary column ( $25 \mathrm{~m}$ length by $0.22 \mathrm{~mm}$ internal diameter) containing WCOT OV-1 $(0.3 \mathrm{~mm}$ film thickness, Spiral). A temperature gradient of $100-290^{\circ} \mathrm{C}$ at $5{ }^{\circ} \mathrm{C} \mathrm{min}{ }^{-1}$, followed by a $10 \mathrm{~min}$ isotherm plateau at $290^{\circ} \mathrm{C}$, was used.

GC-MS analysis was conducted on a Hewlett Packard 5890 gas chromatograph connected to a Hewlett Packard 5989A mass spectrometer. Samples were injected in the splitless mode. The column was a $12 \mathrm{~m} \mathrm{HP}-1$. A temperature gradient of $100-290{ }^{\circ} \mathrm{C}\left(8^{\circ} \mathrm{C} \mathrm{min}^{-1}\right)$ was used.

Experiments with lipid bilayer membranes. Black lipid bilayer membranes were formed as described previously (Benz et al., 1978). The instrumentation consisted of a Teflon chamber with two aqueous compartments connected by a small circular hole. The hole had a surface area of about $0.5 \mathrm{~mm}^{2}$. Membranes were formed across the hole by painting on a $1 \%$ solution of a mixture (molar ratio 4:1) of diphytanoyl phosphatidylcholine (PC) and phosphatidylserine (PS) (Avanti Polar Lipids, Alabaster AL) in $n$-decane.

\section{Electron microscopy}

Transmission electron microscopy. Bacterial pellets were fixed for $1 \mathrm{~h}$ at $4{ }^{\circ} \mathrm{C}$ with $2.5 \%(\mathrm{w} / \mathrm{v})$ glutaraldehyde and $0.05 \mathrm{M}$ lysine in a $0 \cdot 1 \mathrm{M}$ cacodylate buffer $(\mathrm{pH} 7 \cdot 4)$ containing, or not, $0.075 \%(\mathrm{w} / \mathrm{v})$ ruthenium red. Cells were washed five times in the same buffer, i.e. with or without $0.075 \%(\mathrm{w} / \mathrm{v})$ ruthenium red, and postfixed for $1 \mathrm{~h}$ at room temperature in $1 \%(\mathrm{w} / \mathrm{v})$ osmium tetroxide containing, or not, $0.075 \%$ (w/v) ruthenium red in cacodylate buffer ( $\mathrm{pH} 7 \cdot 4)$, and then rinsed with distilled water. Bacteria were suspended in $1 \%(\mathrm{w} / \mathrm{v})$ aqueous uranyl acetate for $1 \mathrm{~h}$ at room temperature and then washed five times in distilled water. Suspended cells were embedded in $2 \%$ molten agar type IX (Sigma) before dehydration through a graded ethanol series. Dehydrated cells were embedded in Spurr medium with intermediate 1,2epoxypropane infiltration. Blocks were conventionally cut, stained and examined with a Philips CM12 microscope operating under standard conditions.

Freeze-etched preparations for electron microscopy. Bacterial suspensions were centrifuged at $5000 \mathrm{~g}$. A drop of the pellet was placed between thin copper holders and quenched in liquid propane. The frozen samples were fractured at $-125^{\circ} \mathrm{C}$ in a vacuum of about $10^{-7}$ torr as described by Aggerbeck \& Gulik-Krzywicki (1986). The fractured samples were etched at $-100{ }^{\circ} \mathrm{C}$ for $3 \mathrm{~min}$ at $1.3 \times 10^{-5} \mathrm{~Pa}$ and then replicated with 
1-1.5 nm of deposits of platinum-carbon, and backed with about $20 \mathrm{~nm}$ of carbon. The replicas were cleaned overnight with chromic acid, washed with distilled water and observed with a Philips 410 electron microscope.

\section{RESULTS}

\section{Ultrastructure of the cell envelopes of corynebacteria}

Electron microscopic examination of ultrathin sections from conventionally fixed corynebacterial cells (Fig. 1a, $\mathrm{d}$, e) revealed a cell envelope structure composed of (i) a plasma membrane (PM) of 6-7 nm, (ii) a thick electrondense layer (EDL) of $15-20 \mathrm{~nm}$, (iii) an electrontransparent layer (ETL) of 7-8 nm and (iv) a thin outer layer (OL) of 2-3 nm. This ultrastructural appearance of the cell envelope of corynebacteria is similar to that found in mycobacteria (Daffé \& Draper, 1998; Draper, 1982; Paul \& Beveridge, 1992; Rastogi et al., 1986). However, in contrast to mycobacteria, in which a space is observed between the PM and EDL corresponding to a hypothetical periplasmic space (Daffé \& Draper, 1998), the PM is tightly associated to the EDL in thin sections of corynebacteria, an observation consistent with a previous report on C. glutamicum (Marienfeld et al., 1997). When ultrathin sections were stained with ruthenium red, a stain that has been previously shown to react strongly with the surface of mycobacteria (Rastogi et al., 1984), a much thicker OL $(35-40 \mathrm{~nm})$ was seen around the various corynebacteria (Fig. 1b, c, f). Thus, as previously suggested (Daffé \& Draper, 1998), the thin margin observed for OL in conventionally fixed cells and freeze-substituted samples of both corynebacteria (Marienfeld et al., 1997) and mycobacteria (Paul \& Beveridge, 1992) may not reflect the original thickness of the layer. In addition, no difference was seen between ultrathin sections of the parent strain of C. glutamicum (Fig. 1b) and its isogenic mutant devoid of S-layer (Fig. $1 \mathrm{c})$, in terms of either staining properties or thickness; this observation indicated that, in contrast with a previous suggestion (Marienfeld et al., 1997), the OL is not synonymous with the S-layer.

\section{Nature of the outermost bacterial materials}

The molecular composition of the outer bacterial surface of these bacteria is poorly documented, except for the presence of ordered arrays (S-layer) on the surface of $C$. glutamicum and some other corynebacterial strains (Chami et al., 1995; Peyret et al., 1993; Soual-Hoebeke et al., 1999). Therefore, the extracellular material from strains grown on minimal medium, as well as the substances extracted by gentle shaking with glass beads (Ortalo-Magné et al., 1995, 1996) from extensively washed actively growing cells (surface-exposed materials), from various strains of corynebacteria were analysed for their macromolecule and lipid compositions, in conditions of minimal bacterial lysis (as revealed by the absence in the filtrates of any detectable activity of the

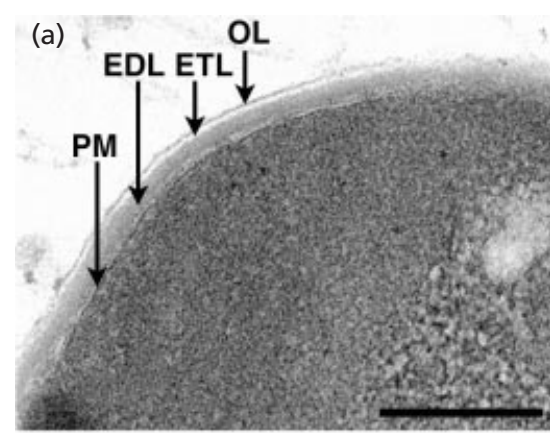

(d)

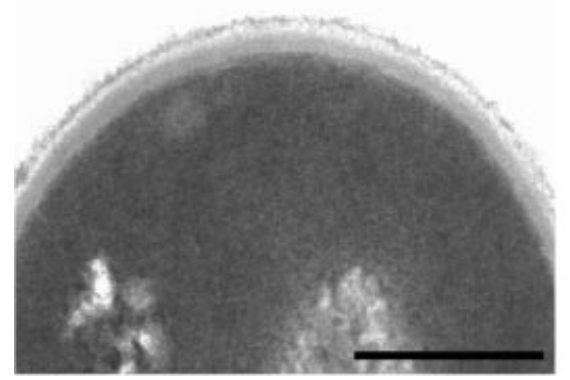

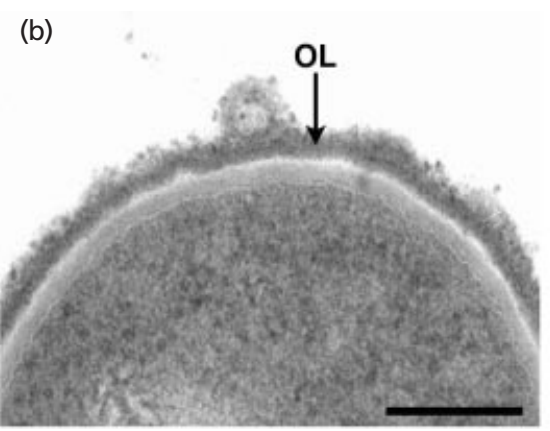

(e)

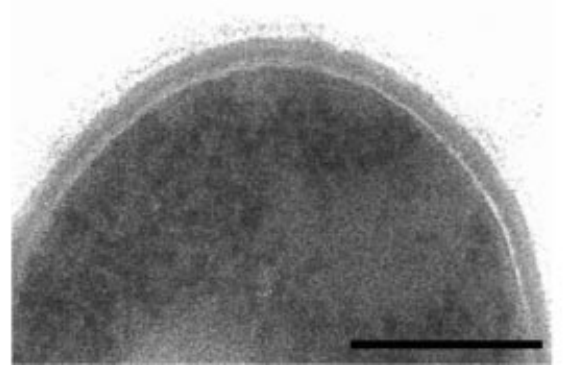

(c)
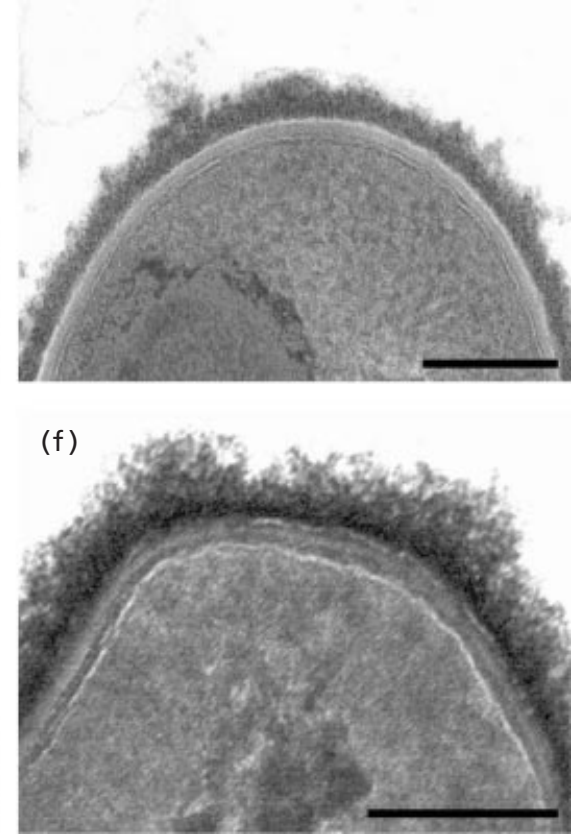

Fig. 1. Thin sections of corynebacteria prepared by conventional embedding. Bacterial pellets were fixed for $1 \mathrm{~h}$ at $4{ }^{\circ} \mathrm{C}$ with $2.5 \%(\mathrm{w} / \mathrm{v})$ glutaraldehyde and $0.05 \mathrm{M}$ lysine in a $0.1 \mathrm{M}$ cacodylate buffer containing $(\mathrm{b}, \mathrm{c}, \mathrm{f})$ or not $(\mathrm{a}, \mathrm{d}, \mathrm{e}) 0.075 \%$ (w/v) ruthenium red. (a) and (b) C. glutamicum CGL2005 (PS2 ${ }^{+}$); (c) C. glutamicum CGL2025 (PS2) ; (d) C. xerosis (ATCC $373^{\top}$ ); (e) and (f) C. amycolatum (ATCC $49368^{\top}$ ). OL, outer layer; ETL, electron-transparent layer; EDL, electron-dense layer; PM, plasma membrane. Bars, $200 \mathrm{~nm}$. 
Table 1. Relative percentages of carbohydrate, proteins and lipids in the surface-exposed materials and culture media from corynebacteria

Exponentially grown corynebacteria were harvested. Surface-exposed materials (beads) were obtained from wet cells by extraction with $4 \mathrm{~mm}$ glass beads. The corresponding materials and culture media were sterilized by filtration. The surface-exposed materials and aliquots of the culture filtrates were assayed for carbohydrate and protein; the remaining culture media were extracted with organic solvents. The resulting lipids were dried and weighed as described in Methods. The lipid contents of the culture media were expressed relative to both macromolecules (carbohydrate + protein) and the cell dry masses $(*)$.

\begin{tabular}{|c|c|c|c|c|c|}
\hline \multirow[t]{2}{*}{ Strain } & \multicolumn{2}{|c|}{ Beads } & \multicolumn{3}{|c|}{ Media } \\
\hline & Carbohydrate & Protein & Carbohydrate & Protein & Lipid \\
\hline C. xerosis ATCC $373^{\mathrm{T}}$ & 98 & 2 & 99 & $0 \cdot 7$ & $0 \cdot 3\left(10^{*}\right)$ \\
\hline C. amycolatum ATCC $49368^{\mathrm{T}}$ & 98 & 2 & 98 & $0 \cdot 5$ & $1 \cdot 1(17)$ \\
\hline C. diphtheriae C8r $(-) \mathrm{Tox}^{-}$ & 93 & 7 & 96 & 2 & $2(33)$ \\
\hline C. glutamicum CGL2005 & 99 & 1 & 94 & 3 & $3(10)$ \\
\hline
\end{tabular}

cytosolic isocitrate dehydrogenase enzyme activity). The extracellular and cell surface macromolecules of corynebacteria which arose from the ethanol precipitation consisted primarily of carbohydrate $(90 \%)$; protein represented less than $10 \%$ of the macromolecules (Table 1). Lipids extracted both from the culture filtrates and from surface-exposed materials consisted mainly of trehalose dicorynomycolate (TDCM) and trehalose monocorynomycolate (TMCM), except for C. amycolatum, where these glycolipids were absent; small amounts of phospholipids, notably phosphatidyl inositoldimannosides and phosphatidyl glycerol, were also detected (data not shown). Interestingly, the same qualitative lipid composition was found for the whole bacteria, showing that all the classes of lipid were exposed on the cell surface of corynebacteria, in sharp contrast to what has been observed for mycobacteria where selective classes of lipid were found exposed on the cell surface (Ortalo-Magné et al., 1996).

Corynebacteria also differed from mycobacteria by the presence of relatively large amounts of lipids in their culture filtrates (Table 1) while only traces of lipid, if any, were found in the extracellular fluids of mycobacteria (Lemassu \& Daffé, 1994; Lemassu et al., 1996). Besides, extracellular lipids were present in both the cspB-disrupted C. glutamicum mutant CGL2025, which is devoid of a surface ordered S-layer (Peyret et al., 1993), and its parent strain CGL2005, suggesting that the presence of an S-layer does not prevent the secretion of lipid into the culture medium.

\section{Chemical analysis of the corynebacterial outermost polysaccharides}

Analysis of the acid hydrolysis products originated from the extracellular and surface-exposed macromolecules of the various strains by GC showed that the sugar composition of the outermost constituents of the vast majority of the corynebacterial species analysed was similiar to that in mycobacteria (Lemassu \& Daffé,
1994; Lemassu et al., 1996; Ortalo-Magné et al., 1995); these were 10-20\% arabinose (Ara), 20-35\% mannose (Man) and $50-70 \%$ glucose (Glc). The outermost polysaccharides from C. amycolatum were almost exclusively composed of Glc. To characterize the polysaccharides that are composed of these sugar residues, the crude ethanol precipitates from the extracellular and surface-exposed macromolecules were further investigated; the precipitates were first treated with proteases and then chromatographed on an ionexchange column (Lemassu \& Daffé, 1994). In both cases, most of the carbohydrate material $(>90 \%)$ was eluted from the column with the buffer containing no salts (data not shown), indicating that they were composed of neutral substances; gel-filtration chromatography over a Bio-Gel P-10 column led to the isolation of three fractions (Fig. 2a). The major fraction (peak A) was exclusively composed of Glc and was eluted in the void volume; gel-filtration chromatography over a Sephadex G-200 column of the glucan fraction led to the isolation of a single peak $A_{1}$ at a position corresponding to an apparent molecular mass of $110 \mathrm{kDa}$ (Fig. 2b). The second peak of the Bio-Gel P-10 column (peak B, Fig. 2a) contained Ara and Man (in a molar ratio of 1:1) and exhibited an apparent molecular mass of $13 \mathrm{kDa}$. The last fraction eluted from the BioGel P-10 column was a large, broad peak (peak C, Fig. 2a) and contained Ara, Man and Glc; gel-filtration chromatography over a Bio-Gel P-4 column of this material gave two peaks (Fig. 2c) at positions corresponding to apparent molecular masses of $1.7 \mathrm{kDa}$ (peak $\mathrm{C}_{1}$, glucan, Fig. 2c) and $1 \mathrm{kDa}$ (peak $\mathrm{C}_{2}$, arabinomannan, Fig. 2c). A similar pattern was observed when the macromolecules derived from the culture filtrate of C. xerosis were analysed. Thus, like mycobacteria (Lemassu \& Daffé, 1994; Lemassu et al., 1996; OrtaloMagné et al., 1995), C. xerosis elaborates extracellular and surface-exposed polysaccharides composed of a $110 \mathrm{kDa}$ high-molecular-mass glucan and a $13 \mathrm{kDa}$ arabinomannan. In contrast to what was found in mycobacteria, low-molecular-mass arabinomannan and 

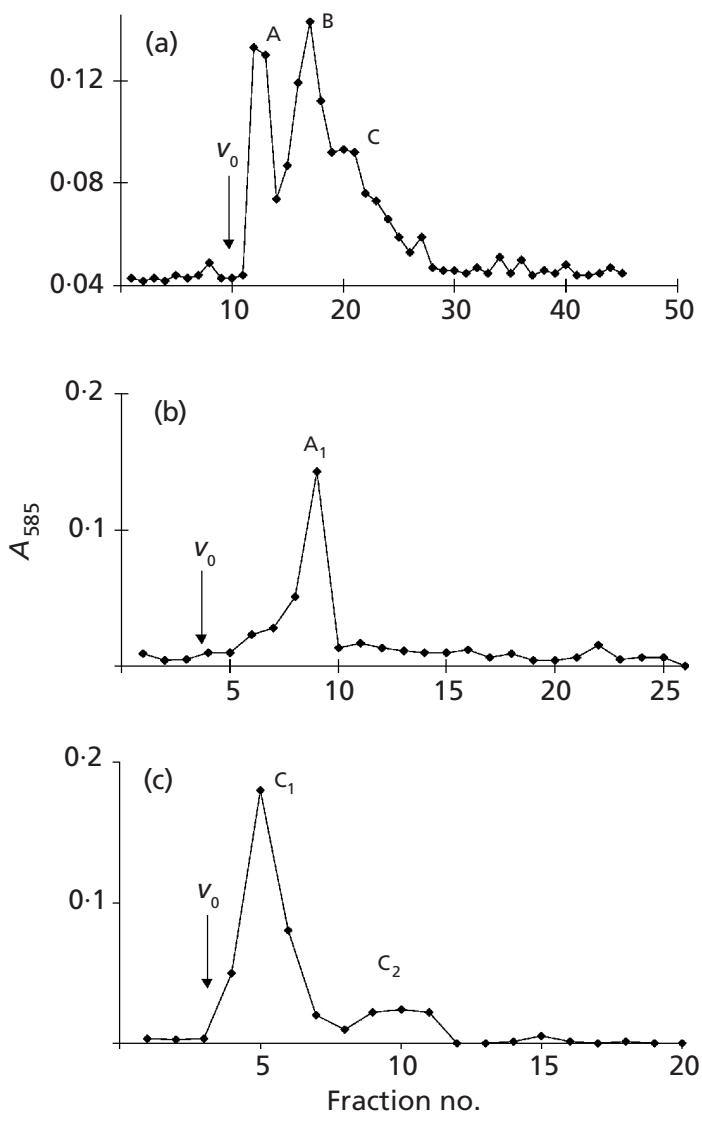

Fig. 2. Gel filtration profiles of the extracellular and surfaceexposed polysaccharides of $C$. xerosis (ATCC $373^{\top}$ ) grown on synthetic medium. (a) Neutral polysaccharides were fractionated on a column of Bio-Gel P-10 $(90 \mathrm{~cm} \times 1.8 \mathrm{~cm})$; (b) fraction A from the Bio-Gel P-10 column was rechromatographed on a column of Sephadex G-200 $(90 \mathrm{~cm} \times 1.8 \mathrm{~cm})$. (c) fraction C from the Bio-Gel P-10 column was rechromatographed on a column of Bio-Gel P-4 $(90 \mathrm{~cm} \times 1.8 \mathrm{~cm})$. The eluant of the gel filtration columns consisted of $1 \%(\mathrm{a}, \mathrm{b})$ and $0.5 \%$ acetic acid (c). Fractions, $5 \mathrm{ml}$ in (a), $9 \mathrm{ml}$ in (b) and $6.5 \mathrm{ml}$ in (c), were collected, and the carbohydrate content of each fraction was determined by colorimetric method. $V_{0}$, void volume.

glucan were present in the mixture of polysaccharides from the strains examined.

\section{Non-covalently associated cell envelope lipopolysaccharides}

The occurrence of arabinomannans in the extracellular and surface-exposed materials from corynebacteria led us to examine the existence of their lipidated forms, i.e. lipoarabinomannan (LAM) in the bacteria. On the basis of preliminary experiments using SDS-PAGE, which showed the occurrence of broad carbohydrate bands, the putative lipopolysaccharides were extracted from corynebacterial cells with hot phenol/water (Leopold \& Fisher, 1993); as expected, Ara and Man were identified by GC analysis of the acid hydrolysis products of all the hot phenol/water extracts. Analysis by SDS-PAGE revealed two broad bands (in the region of $20-40 \mathrm{kDa}$ ) (a)



(b)

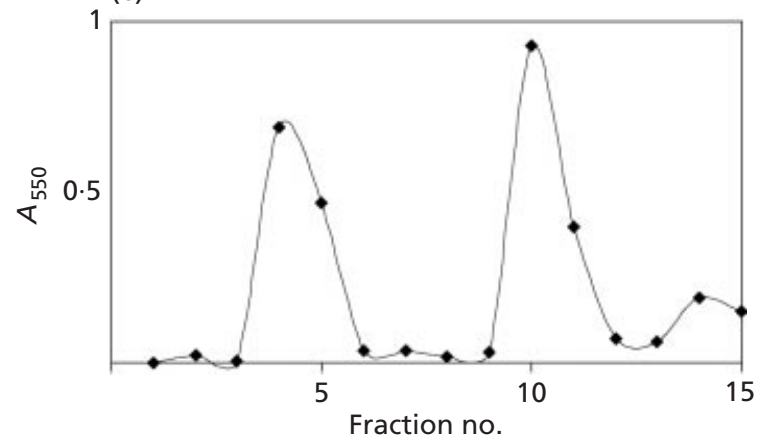

Fig. 3. SDS-PAGE analysis and hydrophobic interaction chromatography of the lipoglycans extracted from corynebacteria. (a) Gel electrophoresis of an authentic sample of mycobacterial lipoarabinomannan (mLAM) and lipomannan (mLM) (lane 1) and of hot phenol/water extracts from $C$. glutamicum CGL2005 (lane 2), C. diphtheriae (strain $\mathrm{C}_{\mathrm{r}}(-)$ Tox ${ }^{-}$) (lane 3), C. xerosis (ATCC $373^{\top}$ ) and C. amycolatum (ATCC $\left.49368^{\top}\right)$. Positions of size markers are shown on the left. CLAM ${ }_{1}$, corynebacterial lipoarabinomannan with a long polysaccharide chain; $\mathrm{CLAM}_{2}$, corynebacterial lipoarabinomannan with a short polysaccharide chain; CLM, corynebacterial lipomannan. (b) Hydrophobic interaction chromatography profile of the crude aqueous phase from the phenol/water extract from $C$. glutamicum on a column of octyl-Sepharose $(10 \mathrm{~cm} \times 0.5 \mathrm{~cm})$. The column was equilibrated in $0.1 \mathrm{M}$ sodium acetate buffer containing $15 \%$ propan-1-ol and first eluted with the buffer $(3 \mathrm{ml})$ and then with a discontinuous gradient of propan-1-ol $(15-100 \%, 3 \mathrm{ml}$ each). Fractions of $1 \mathrm{ml}$ were collected, and the carbohydrate content of each fraction was determined by a colorimetric method.

in all the crude aqueous extracts (Fig. 3a). Based on their electrophoretic properties, similar to those of authentic samples of mycobacterial LAM and lipomannan (LM), used as control, these data suggested the presence of LAM- and/or LM-like substances in corynebacteria and are in agreement with a previous observation (Sutcliffe, 1995). Compared to mycobacterial lipoglycans, however, the major amphiphilic substances from corynebacteria exhibited significantly faster mobilities on gels. To characterize these substances further, the crude amphiphilic fractions from C. glutamicum and C. xerosis were chromatographed on octyl-Sepharose gels (Leopold \& Fisher, 1993) irrigated with a discontinuous gradient of propan-1-ol (15-100\%); two carbohydrate peaks were obtained in both cases (Fig. 3b). The first peak contained non-lipidated polysaccharides, and probably nucleic acids (Leopold \& Fisher, 1993), eluted at 
Table 2. Glycosyl-linkage compositions of arabinogalactans from corynebacteria

Purified cell walls were $O$-methylated, hydrolysed, reduced and acetylated as described in Methods. The resulting partially $O$-methylated, partially $O$-acetylated samples were analysed by GC-MS. -, Not detected; t, terminal; Araf, arabinofuranosyl residue; Gal $f$, galactofuranosyl residue; Glc $p$, glucopyranosyl residue; Manp, mannopyranosyl residue.

\begin{tabular}{|c|c|c|c|c|}
\hline Glycosyl residue & $\begin{array}{l}\text { C. glutamicum } \\
\text { CGL2005 }\end{array}$ & $\begin{array}{c}\text { C. diphtheriae } \\
\text { C8r }(-) \text { Tox }^{-}\end{array}$ & 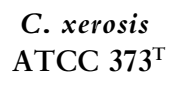 & $\begin{array}{l}\text { C. amycolatum } \\
\text { ATCC } 49368^{\mathrm{T}}\end{array}$ \\
\hline $\mathrm{t}$-Araf & $10 \cdot 0$ & $6 \cdot 0$ & $22 \cdot 0$ & $20 \cdot 0$ \\
\hline 2-Araf & $8 \cdot 0$ & $7 \cdot 0$ & - & - \\
\hline 5-Araf & $61 \cdot 0$ & $48 \cdot 0$ & $38 \cdot 0$ & $35 \cdot 0$ \\
\hline 3,5-Araf & $10 \cdot 0$ & - & $11 \cdot 0$ & $12 \cdot 5$ \\
\hline 2,5-Araf & - & $3 \cdot 5$ & $5 \cdot 0$ & $6 \cdot 0$ \\
\hline $\mathrm{t}-\mathrm{Gal} f$ & - & $2 \cdot 0$ & $2 \cdot 0$ & $1 \cdot 0$ \\
\hline 5-Galf & $6 \cdot 0$ & $13 \cdot 0$ & $8 \cdot 0$ & $12 \cdot 0$ \\
\hline 6-Galf & $2 \cdot 5$ & $3 \cdot 5$ & $2 \cdot 0$ & $2 \cdot 5$ \\
\hline 5,6-Galf & $2 \cdot 5$ & $10 \cdot 0$ & - & - \\
\hline 2,5-Galf & - & - & $5 \cdot 0$ & $2 \cdot 5$ \\
\hline $\mathrm{t}-\mathrm{Glc} p$ & - & - & $2 \cdot 0$ & $2 \cdot 5$ \\
\hline 6-Glcp & - & - & $2 \cdot 0$ & $1 \cdot 0$ \\
\hline 2,6-Glcp & - & - & $5 \cdot 0$ & $4 \cdot 0$ \\
\hline $\mathrm{t}-\operatorname{Man} p$ & - & $3 \cdot 0$ & - & - \\
\hline 2-Manp & - & $3 \cdot 0$ & - & - \\
\hline
\end{tabular}

the initial concentration of $15-30 \%$ propanol. The second major carbohydrate peak, which was eluted from the gel with 50-60\% propanol, contained most of the LAM- and LM-like substances, as judged by SDSPAGE, suggesting that these occur in the aqueous phenol extracts in their acylated forms. Fatty acid methyl esters resulting from the methanolysis of the second peaks originated from both strains consisted of $\mathrm{C}_{16: 0}$ and $\mathrm{C}_{18: 1}$, the major fatty acyl substituents identified in the saponification products of whole bacteria. Analysis of the acid hydrolysis products from this latter fraction showed a Ara:Man molar ratio of $1: 8$ and $1: 2$ for samples originating from C. glutamicum and C. xerosis, respectively. Based on the SDS-PAGE and GC profiles it was concluded that lipopolysaccharides of C. glutamicum corresponded primarily with LM-like substances (cLM, Fig. 3a), with small amounts of LAM-like molecules (cLAM ${ }_{1}$, Fig. 3a); the lipoglycans of C. xerosis consisted of LAM-like compounds. It is suggested that C. xerosis possesses two types of LAMs, i.e. CLAM 1 and another class of LAM $\left(\mathrm{cLAM}_{2}\right.$, Fig. 3a) possessing a carbohydrate moiety much shorter than those of mycobacterial LAM (mLAM) and $\mathrm{CLAM}_{1}$; this hypothesis is based on the carbohydrate content of the fraction and its mobility on SDS-PAGE, and is consistent with the occurrence of two types of arabinomannans and the lack of detection of mannan in the extracellular and surfaceexposed materials of this species (see above).

\section{Analysis of cell wall arabinogalactans}

The cell walls of corynebacteria and closely related genera are typified by the presence of a polysaccharide composed mainly of D-arabinofuranosyl and D-gal- actosyl (Gal) residues, arabinogalactan (AG), which is covalently attached to peptidoglycan. The glycosyl compositional analysis of the purified cell wall AG from the various corynebacteria examined demonstrated that all the strains, including those belonging to C. amycolatum which are devoid of corynomycolates, elaborated AG consisting primarily of Ara and Gal (Table 2), but may also have contained other sugar constituents. Based on their glycosyl compositions, the six species examined could be divided into three groups: (i) C. glutamicum, in which AG is composed only of Ara and Gal, (ii) C. diphtheriae, which contained significant amounts of Man residues in its AG, and (iii) C. amycolatum and C. xerosis, whose AG contained Glc; these data are consistent with the reported occurrence of Man and Glc in the AG of some corynebacteria (Abou-Zeid et al., 1982).

Detailed structural studies of AG from mycobacteria, rhodococci and nocardiae (Daffé et al., 1990, 1993) showed that the major structural features of AG are genus-specific in mycobacteria and species- or strainspecific in the two other bacterial groups; similar conclusions could also be drawn from the glycosyllinkage compositions. Consequently, cell wall AGs from representative strains of the three types of glycosyl composition were isolated and analysed for their glycosyl-linkage composition through the characterization of the different partially $\mathrm{O}$-methylated partially $\mathrm{O}$-acetylated alditols (Table 2). While the glycosyl-linkage composition of AG from C. glutamicum was very similar to that of mycobacteria (Daffé et al., 1990, 1993), those of AG from the other two groups of corynebacteria were unique; the glycosyl-linkage composition of AG from C. diphtheriae differed from those published so far by the 
absence of 3,5-linked Ara whereas those of C. amycolatum and C. xerosis were typified by the absence of 2linked Ara and the occurrence of 6- and 2,6-linked glucosyl units, two types of glucosyl units not present in the mycobacterial glucan (Lemassu \& Daffé, 1994; Lemassu et al., 1996). The glycosyl-linkage compositions of C. diphtheriae, C. amycolatum and C. xerosis were, however, related to those reported for AG from corynebacteria, nocardiae and rhodococci where 2,5-linked Ara has been found (Daffé et al., 1993; AbouZeid et al., 1982). A comparative chromatography on a Bio-Gel P-10 column of AGs from corynebacteria and mycobacteria indicated that both polysaccharides exhibited an apparent molecular mass of $15 \mathrm{kDa}$ (data not shown).

\section{Distribution of the corynomycoloyltransferase PS1 and the S-layer constituent PS2 in corynebacteria}

It was recently demonstrated that one of the two major secreted protein from C. glutamicum, PS1, possesses a mycoloyltransferase activity in this species (Puech et al., 2000). However, like the other major secreted S-layer constituent, PS2, the occurrence of PS1 in different corynebacteria has not been investigated. To determine the distribution of PS1, proteins extracted from the outermost cell envelope compartment were analysed by SDS-PAGE. Compared to those of mycobacteria (Ortalo-Magné et al., 1995), the protein profiles of corynebacteria were less complex (Fig. 4a), consisting only of a few major bands, notably three bands with electrophoretic migrations similar to those of PS1 and PS2 (in the $60-70 \mathrm{kDa}$ region). To characterize these proteins further, Western blot analyses were performed on them using polyclonal antibodies directed against PS1 and PS2. The anti-PS1 antibodies reacted strongly with polypeptide bands exhibiting the corresponding molecular mass in C. glutamicum (positive control, Fig. 4b, lane 1), one strain of C. xerosis (ATCC 9016; Fig. 4b, lane 3 ) and C. amycolatum (Fig. 4b, lane 5), and gave a faint reaction with proteins from C. diphtheriae (Fig. 4b, lane 4) and the type strain of C. xerosis (Fig. 4b, lane 2). In these latter strains, stronger reactions were observed with other polypeptides which may share some epitopes with PS1. Although the corynomycoloyltransferase activity of PS1 (Puech et al., 2000) was not investigated, these data suggest the presence of PS1 in all the strains examined, including in those devoid of corynomycolates, i.e. C. amycolatum (Collins et al., 1988; Barreau et al., 1993). In contrast, the anti-PS2 antibodies reacted only with proteins originated from the $\mathrm{PS}^{+}$parent strain of C. glutamicum (positive control); proteins from the PS2 ${ }^{-}$strain CGL2025 of C. glutamicum (cspBdisrupted mutant, negative control), as well as those from the other corynebacterial strains examined did not react with the anti-PS2 antibodies (data not shown). Although the production of PS2 was shown to greatly depend on the carbon source (Soual-Hoebeke et al., 1999), the failure to detect this protein was not attributed to the growth medium used to analyse the other corynebacterial strains since all the strains examined
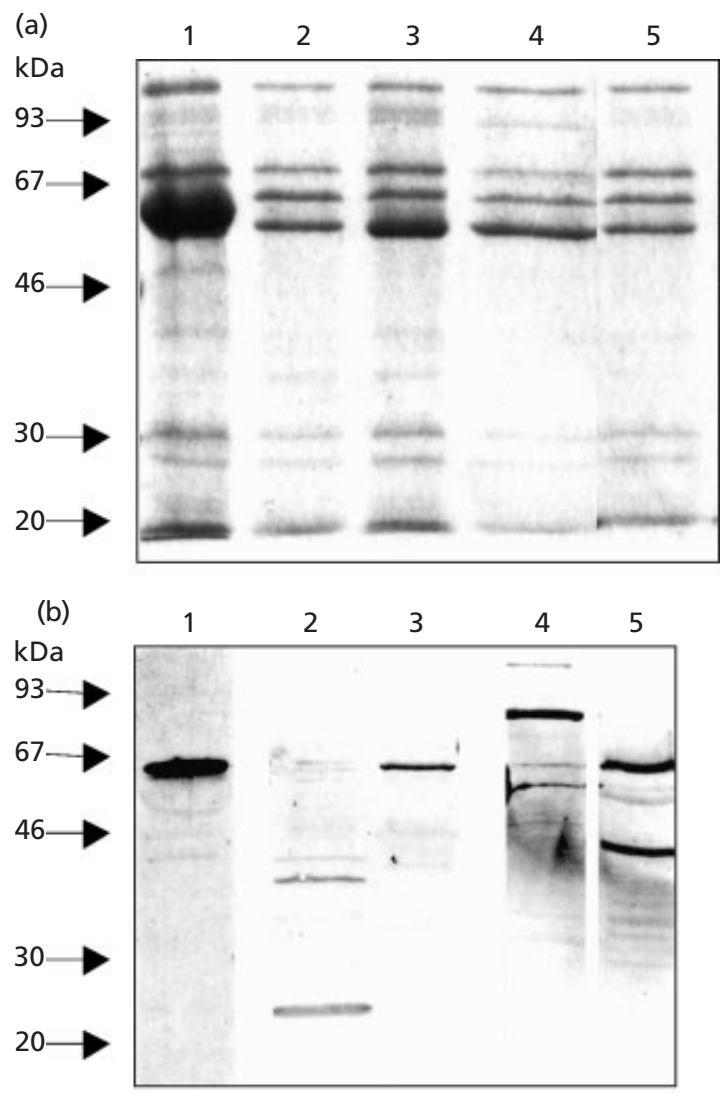

Fig. 4. SDS-PAGE and Western blot analyses of cell wall proteins of corynebacteria. Protein associated with the cell wall of bacteria were extracted with $2 \%(\mathrm{w} / \mathrm{v}) \mathrm{SDS}$ in $50 \mathrm{mM}$ Tris/ $\mathrm{HCl}$ at $100{ }^{\circ} \mathrm{C}$ for $2 \mathrm{~min}$ and analysed on acrylamide gels; protein bands were either stained with Coomassie blue (a) or blotted onto nitrocellulose membrane, probed with rabbit anti-PS1 polyclonal antibodies and bands detected using alkalinephosphatase-conjugated antibodies and nitro blue tetrazolium (NBT)/5-bromo-4-chloro-3-indoxyl phosphate (BCIP) p-toluidine as substrates (b). Positions of size markers are shown on the left. (a) Lane 1, C. glutamicum CGL1009 (overexpressing PS2); lane 2, C. amycolatum (ATCC $49368^{\top}$ ); lane 3, C. xerosis (ATCC $373^{\top}$ ); lane 4, C. diphtheriae (strain $\mathrm{C}_{\mathrm{r}}(-)$ Tox ${ }^{-}$; lane 5, C. pseudodiphtheriticum (strain Breuillaud). (b) Lane 1, C. glutamicum CGL2005; lane 2, C. xerosis (ATCC $373^{\top}$ ); lane 3, C. xerosis (ATCC 9016); lane 4 , C. diphtheriae (strain $C 8_{\mathrm{r}}(-)$ Tox ${ }^{-}$); lane $5, C$. amycolatum (ATCC 49368').

were grown on the same BHI medium, which had been shown to allow C. glutamicum strain CGL2005 to produce a highly ordered surface layer composed of PS2 (Chami et al., 1995; Peyret et al., 1993). It was thus concluded that the S-layer component PS2 was absent from most of the strains examined herein.

Although PS2 was not detected by Western blotting of the outer surface proteins of most corynebacterial strains examined herein, the lack of detection of the protein could be due to the production of only a tiny amount of PS2 by these strains. In addition, some corynebacterial species may produce a surface layer composed of proteins other than PS2. Since freeze-etching electron 

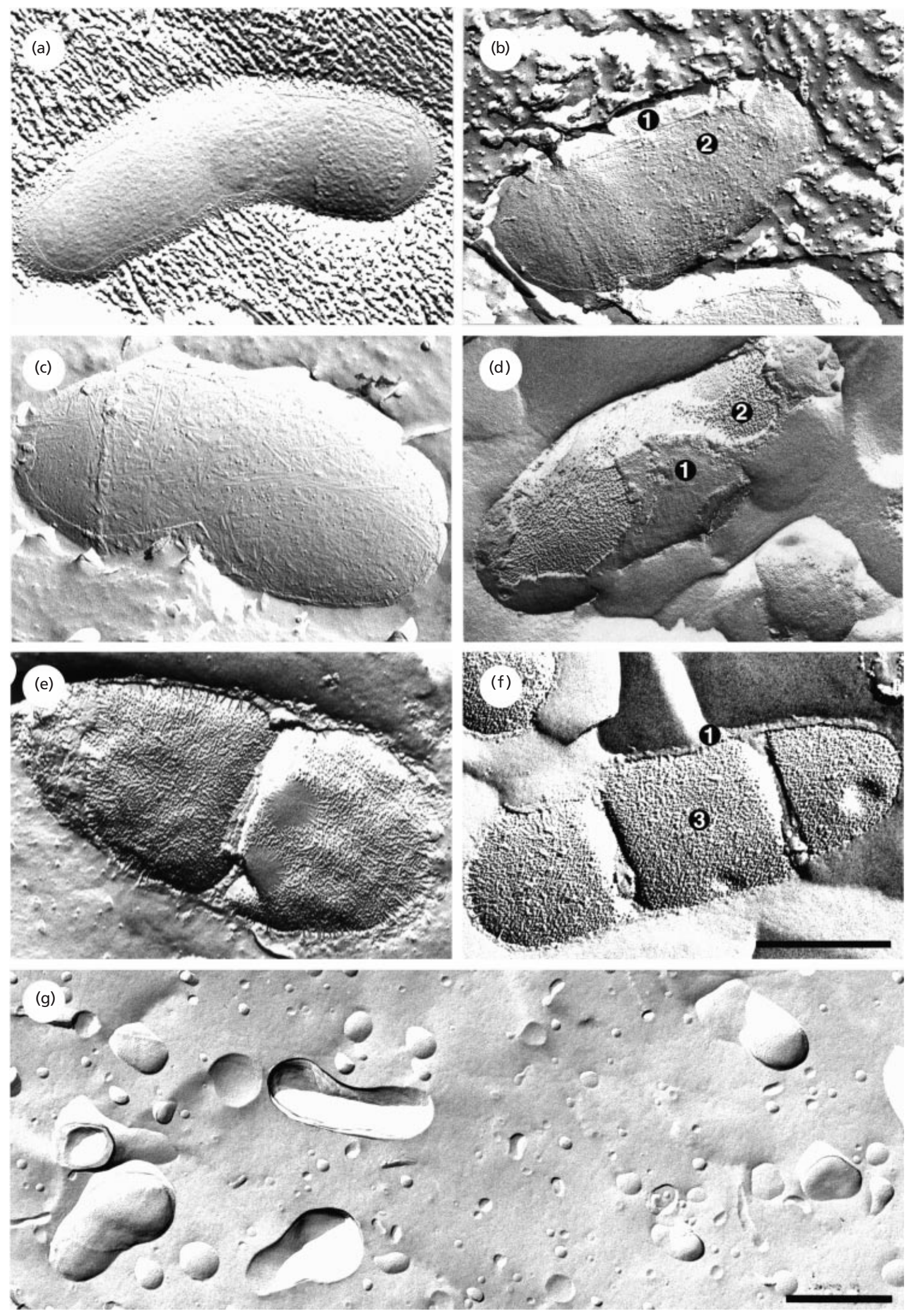

Fig. 5. For legend see facing page. 
microscopy has proved to be a sensitive technique for the detection of crystalline S-layer, this technique was used to investigate the occurrence of ordered arrays on the various corynebacterial strains studied. Apart from the strain of C. glutamicum carrying the $c s p B$ gene (Peyret et al., 1993; Chami et al., 1995; data not shown from this study), no appearance of S-layer was visible on the other strains examined (Fig. 5). It was thus concluded that the other strains do not produce S-layer. Some interesting species-specific features were also observed; for instance, a filamentous surface, similar to that described for mycobacteria, was seen in C. pseudodiphtheriticum (Fig. 5c).

\section{Presence, distribution and localization of porins in corynebacteria}

Pore-forming polypeptides (porins) have been recently characterized in C. glutamicum as low-molecular-mass peptides (Lichtinger et al., 1998) but the location of these proteins and their distribution in other members of the genus Corynebacterium have not been investigated. Thus, SDS-PAGE analysis was performed on the different cell fractions (extracellular, surface-exposed, crude cell wall, membrane proteins) of various corynebacterial strains and proteins were blotted and analysed by Western blotting using polyclonal antibodies directed against corynebacterial porins (Fig. 6a). Positive reactions were observed with polypeptide bands exhibiting small molecular masses from extracellular, surfaceexposed, crude cell wall materials, but not with plasma membrane fractions of C. glutamicum, C. diphtheriae (Fig. 6a), C. xerosis ATCC 7711, 7094 and 9016, and C. pseudodiphtheriticum; no reaction was found, however, with the corresponding materials from C. amycolatum and the type strain of C. xerosis (Fig. 6a). To confirm that these polypeptide bands corresponded to porins, the various materials were examined for their ability to form channels for the entry of small hydrophilic molecules in lipid bilayer membranes. Materials derived from glass-bead-treated cells, cytosol and plasma fractions from C. diphtheriae and C. pseudodiphtheriticum gave a small amount of channel-forming activity but much higher channel-forming activity (Lichtinger et al., 1998) was always found in the cell wall fractions. No channel-forming activity was detected with cell fractions from C. xerosis. An example of the channel-forming activity of cell wall material of C. diphtheriae is shown in Fig. 6(b). Small amounts of the cell wall fraction were treated with the detergent Genapol. The addition of this material to the aqueous phase bathing a lipid bilayer membrane resulted in a step-wise change in membrane conductance (see
Fig. 6c) caused by the formation of ion-permeable channels in the membrane. The channels were fairly homogeneous as Fig. 6(b) indicates and had a mean single channel conductance of about $2 \cdot 3 \mathrm{nS}$ in $1 \mathrm{M} \mathrm{KCl}$. Only occasionally were channels observed that had twice the conductance of the $2.3 \mathrm{nS}$ channel. It is noteworthy that the cell wall channel of C. glutamicum has a much higher single-channel conductance of $5.5 \mathrm{nS}$ under the same conditions (Lichtinger et al., 1998), an observation which may be related to the physiological differences between the two corynebacterial species; similar observations have been made in mycobacteria, where porins exhibiting different biochemical properties have been described, not only in various species, but also in the same mycobacterial strain (Kartmann et al., 1999; Lichtinger et al., 1999; Mukhopadhyay et al., 1997; Trias et al., 1992; Trias \& Benz, 1994; Senaratne et al., 1998).

\section{Covalently linked corynomycolates and the cell wall fracture plane}

Corynebacteria, mycobacteria and closely related genera are known to produce, in addition to the expected fracture plane within the plasma membrane, a second and main plane within the cell wall when freezefractured preparations of cells are observed by electron microscopy (Benedetti et al., 1984; Chami et al., 1995; Takeo et al., 1984); this plane is postulated to propagate between the mycolate monolayer, formed by the mycoloyl residues which esterify the arabinan termini, and the lipid layer of the outer barrier of these organisms (Daffé \& Draper, 1998; Minnikin, 1982). Thanks to the existence of a corynebacterial species devoid of mycolic acid, i.e. C. amycolatum, and of a pair of isogenic strains of C. glutamicum differing in their cell-wall-associated corynomycolate content (Puech et al., 2000), the question of the contribution of mycolates in the main fracture plane was addressed. Cell wall corynomycolates were isolated from extensively delipidated cells by chromatography of the saponification products; they represented only a small percentage $(0-5 \%)$ of dried corynebacterial mass (Table 3), compared to mycobacteria (roughly $10 \%$ in the case of M. tuberculosis; Jackson et al., 1999). Except for C. amycolatum, the various strains contained corynomycolates. It has to be noted that the different strains labelled C. xerosis differed one from another in terms of the chain length of their corynomycolates; while the type strain of the species (ATCC 373) and strain ATCC 7711, a true C. xerosis (Funke et al., 1996), produced $C_{34}$ and $\mathrm{C}_{36}$ corynomycolates, the other strains elaborated

Fig. 5. Freeze-fractured and deep-etched preparations of corynebacterial strains grown on BHI-containing agar plates (a-f) and cell envelope outermost lipid material (g). (a) C. glutamicum CGL2025 (PS2 ${ }^{-}$); (b) C. diphtheriae (strain C8 $(-)$ Tox ); (c) C. pseudodiphtheriticum (strain Breuillaud); (d) C. xerosis (ATCC 7711); (e) C. xerosis (ATCC $373^{\top}$ ); (f) C. amycolatum (ATCC $49368^{\top}$ ). Note the absence of the ordered surface layer on all the strains examined. Depending on the strains, however, a fracture plane is seen either in the cell wall fracture plane (2) close to the bacterial surface (1) in (a)-(d) or in the plasma membrane (3) in (e) and (f). (g) Crude octylglucoside extract recovered by centrifugation, extensively dialysed and then pelled at $200000 \mathrm{~g}$. Note the fracture plane that occurs within the homogeneous smooth vesicles and indicates that the material analysed spontaneously forms liposomes. Bars, $500 \mathrm{~nm}(\mathrm{a}-\mathrm{f}) ; 400 \mathrm{~nm}(\mathrm{~g})$. 


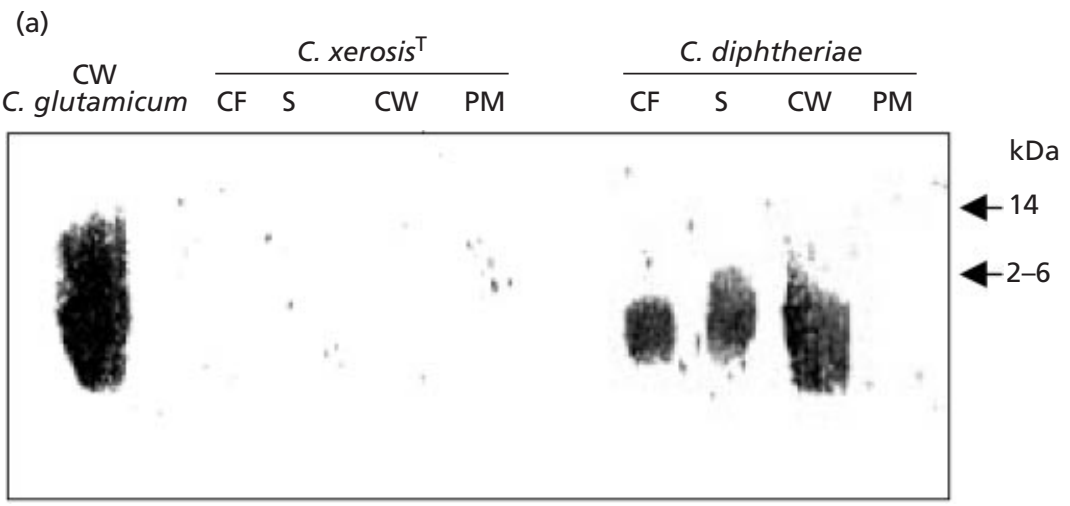

(b)
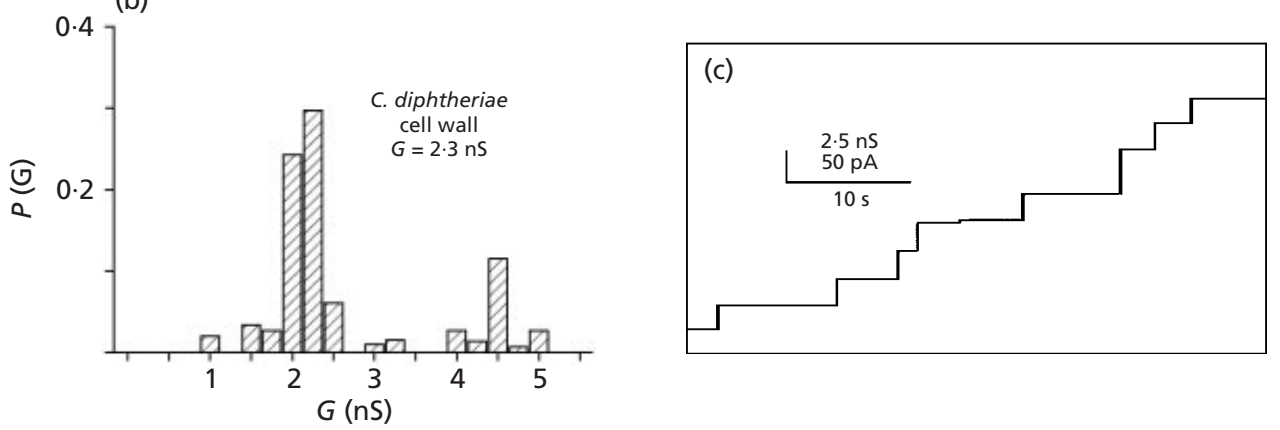

Fig. 6. Distribution and sublocalization of the low-molecular-mass porin in corynebacteria and functional analysis of the cell wall porin of $C$. diphtheriae (strain $\mathrm{C}_{\mathrm{r}}(-)$ Tox ${ }^{-}$). (a) Culture filtrates (CF), surface-exposed (S), cell wall (CW) and plasma membrane (PM) material of various strains were analysed by Western blotting using polyclonal antibodies directed against the low-molecular-mass porin from C. glutamicum. Positions of size markers are shown on the right. (b) Histogram of the probability $P(G)$ of the occurrence of a given conductivity unit observed with membranes formed of phosphatidylcholine/phosphatidylserine (molar ratio $4: 1$ )/n-decane in the presence of the detergent-solubilized cell wall extract of $C$. diphtheriae. $P(G)$ is the probability that a given conductance increment $G$ is observed in the single-channel experiments. It was calculated by dividing the number of fluctuations with a given conductance increment by the total number of conductance fluctuations. The aqueous phase contained $1 \mathrm{M} \mathrm{KCl}, \mathrm{pH} \mathrm{6.0}$; the applied potential was $20 \mathrm{mV}$ at $20^{\circ} \mathrm{C}$. The mean single-channel conductance was $2.3 \mathrm{nS}$ for 148 single-channel events. (c) Single-channel recording of a PC:PS (molar ratio 4:1)/n-decane membrane in the presence of $10 \mu \mathrm{l}$ the cell wall fraction of $C$. diphtheriae treated with $1 \%$ Genapol. The aqueous phase contained $1 \mathrm{M} \mathrm{KCl}, \mathrm{pH} \mathrm{6.0.} \mathrm{The} \mathrm{applied} \mathrm{membrane} \mathrm{potential} \mathrm{was} 20 \mathrm{mV}$ and the temperature was $20^{\circ} \mathrm{C}$.

$\mathrm{C}_{30}$ and $\mathrm{C}_{32}$ chains (Table 3). Furthermore, comparative data from the various strains by biochemical tests (API CORYNE) and fatty acid compositional analysis (data not shown) demonstrated that the other ATCC strains were misidentified and did not correspond to strains of C. xerosis, in agreement with the heterogeneity of this species (Coyle et al., 1993; Funke et al., 1996).

Examination of the various corynebacterial strains by freeze-etch electron microscopy demonstrated that all strains of C. amycolatum exhibited a fracture plane only within the plasma membrane (Fig. 5f). In corynomycolate-containing strains, however, no correlation was found between the occurrence of a fracture plane within the cell wall and the content in cell-wall-associated corynomycolates (Table 3 ). This was particularly true for the type strain of C. xerosis, which exhibited a relatively high cell-wall-associated corynomycolate content, but most frequently exhibited a unique fracture plane within the plasma membrane (Fig. 5e); a small percentage of these cells $(10 \%)$ may, however, show a fracture plane within the cell wall (Fig. 5d). This observation was independent of the origin of the strain (the strain was obtained from three different culture collections), the batches, the carbon source used for the bacterial growth and the various growth phases of the strain. Conversely, the csp1-disrupted mutant of $C$. glutamicum, which contains only $0.5 \%$ of covalently linked corynomycolates, exhibited a cell wall fracture plane superimposable on that of its parent (Fig. 5a). In contrast, in the representative strains of the other species, as well as the other strain of C. xerosis (ATCC 7711), the fracture plane propagated exclusively within their cell wall (Fig. 5, Table 3). These data indicated that the occurrence of a fracture plane within the cell was not attributable to the cell-wall-linked corynomycolate alone.

\section{Non-covalently associated cell envelope lipids}

To explain the occurrence of the cell wall fracture plane in strains exhibiting a very low cell-wall-associated 
Table 3. Lipid analysis and occurrence of the cell wall fracture plane in corynebacteria

Bacteria were extracted with organic solvents to yield non-covalently bound lipids. The residues were saponified and the resulting cell wall-linked corynomycolic acids were extracted with diethyl ether and their percentage (relative to cell dry mass) was determined in two ways (see Methods). The values represent the means of three independent determinations. The chain lengths of corynomycolates were determined by GC-MS; the major chain length is shown in bold. When analysed by freeze-fracture electron microscopy, the fracture plane was observed within the cell wall $(+)$ or the plasma membrane $(-)$ of corynebacteria. While the type strain and strain ATCC 7711 correspond to true C. xerosis the others strains labelled 'C. xerosis' are misidentified (see text).

\begin{tabular}{|c|c|c|c|c|}
\hline Species & $\begin{array}{l}\text { Non-covalently } \\
\text { bound lipids ( } \% \text { ) }\end{array}$ & $\begin{array}{c}\text { Cell-wall-linked } \\
\text { corynomycolic acids (\%) }\end{array}$ & $\begin{array}{l}\text { Major chain } \\
\text { length }\end{array}$ & $\begin{array}{l}\text { Fracture in the } \\
\text { cell wall }\end{array}$ \\
\hline C. amycolatum ATCC $49368^{\mathrm{T}}$ & $3 \cdot 7 \pm 0 \cdot 1$ & 0 & & - \\
\hline C. amycolatum CIP 79.37 & $5 \cdot 1 \pm 0 \cdot 1$ & 0 & & - \\
\hline C. amycolatum CIP 100836 & $5 \cdot 3 \pm 0 \cdot 1$ & 0 & & - \\
\hline C. amycolatum CIP 103818 & $5 \cdot 1 \pm 0 \cdot 1$ & 0 & & - \\
\hline C. amycolatum CIP 103819 & $4 \cdot 1 \pm 0 \cdot 1$ & 0 & & - \\
\hline C. amycolatum CIP 103820 & $6 \cdot 1 \pm 0 \cdot 1$ & 0 & & - \\
\hline C. amycolatum CIP 103821 & $5 \cdot 3 \pm 0 \cdot 1$ & 0 & & - \\
\hline C. xerosis ATCC $373^{\mathrm{T}}$ & $3 \cdot 2 \pm 0 \cdot 1$ & $3 \cdot 5 \pm 0 \cdot 1$ & 34,36 & $-*$ \\
\hline 'C. xerosis' ATCC 7094 & $11 \cdot 8 \pm 0 \cdot 2$ & $1 \cdot 9 \pm 0.05$ & 30,32 & + \\
\hline 'C. xerosis' ATCC 7711 & $12 \cdot 0 \pm 0 \cdot 2$ & $4 \cdot 8 \pm 0 \cdot 1$ & 34,36 & + \\
\hline 'C. xerosis' ATCC 9016 & $10 \cdot 8 \pm 0 \cdot 2$ & $1 \cdot 3 \pm 0 \cdot 5$ & 30,32 & + \\
\hline C. diphtheriae $\mathrm{C} 8 \mathrm{r}(-) \mathrm{Tox}^{-}$ & $8 \cdot 0 \pm 0 \cdot 1$ & $2 \cdot 5 \pm 0 \cdot 1$ & 30,32 & + \\
\hline C. pseudodiphtheriticum Breuillaud & $5 \cdot 8 \pm 0 \cdot 1$ & $2 \cdot 5 \pm 0 \cdot 1$ & 32,34 & + \\
\hline C. glutamicum CGL2005 & $7 \cdot 0 \pm 0 \cdot 1$ & $1 \cdot 0 \pm 0 \cdot 5$ & $32, \mathbf{3 4}, 36$ & + \\
\hline C. glutamicum CGL2022 & $7 \cdot 0$ & $0 \cdot 5$ & $32,34,36$ & + \\
\hline
\end{tabular}

$* 90 \%$ of the cells were devoid of the cell wall fracture plane.

corynomycolate content, we postulated that other lipids may replace corynomycoloyl residues in the inner monolayer of the outer membrane, based on the structural similarities between $\mathrm{C}_{32-36}$ corynomycolatecontaining molecules, e.g. TDCM and TMCM (with two parallel $\mathrm{C}_{16-18}$ chains), and $\mathrm{C}_{16-18}$-containing lipids such as phospholipids. Therefore, non-covalently associated lipids were extracted from bacterial cells grown with organic solvents and weighed (Table 3). Interestingly, strains of C. amycolatum and the type strain of C. xerosis contained 3-6\% of extractable lipids whereas the other corynebacterial strains produced significantly more lipids. TLC analysis of these lipids showed that their composition was similar to that found in the extracellular and surface-exposed materials; TDCM, TMCM and phospholipids were the main substances detectable in all the strains, except C. amycolatum, where only phospholipids were observed. Compared to the outermost lipid materials, however, many more phospholipids were detected in bacterial lipids, as expected from their partiality for plasma membrane. It was thus concluded that the presence of significant amounts of extractable lipids, e.g. TDCM and TMCM, probably contributes to the occurrence of a cell wall fracture plane in corynebacteria.

To evaluate the possible contribution of non-covalently bound lipids in the cell wall permeability barrier, the outermost material of C. glutamicum was extracted with octylglucoside; this method did not affect the integrity of bacterial cells, as judged by freeze-fracture microscopy (data not shown). The crude detergent extract, which contained mostly polysaccharides and lipids, was extensively dialysed to eliminate the detergent and to reconstitute organized structures; it was then centrifuged and the pellet was analysed by freezefracture electron microscopy (Fig. 5g). Homogeneous smooth vesicles whose diameter varied from 50 to $500 \mathrm{~nm}$ were observed throughout the samples analysed, indicating that the material examined spontaneously forms liposomes upon dialysis of the detergent; analysis of the lipid material by TLC showed that it primarily consisted of trehalose dicorynomycolates, with small amounts of phospholipid and trehalose monocorynomycolates. It follows then that the non-covalently bound lipids from the cell envelope of corynebacteria are strong candidates for participating in a membrane-like structure.

\section{DISCUSSION}

Corynebacteria, mycobacteria, nocardiae, rhodococci and closely related genera are members of a distinctive suprageneric actinomycete taxon which includes bacterial species of such biotechnological, medical, veterinary and environmental importance that it is crucial to understand fully their physiology and metabolism 
(Sutcliffe, 1997). From the enormous work that has been devoted to the characterization of members of this taxon, it appeared that many of their distinctive properties were related to their unusual cell envelope composition and architecture, compared to those of other Gram-positive micro-organisms. Consequently, models of the mycobacterial envelope, consistent with their chemical and physical properties, have been proposed (Daffé \& Draper, 1998; Liu et al., 1995; Minnikin, 1982; Rastogi, 1991) and extrapolated to other members of the taxon (Minnikin \& O'Donnell, 1984; Sutcliffe, 1997).

As far as the ultrastructural appearance is concerned, the cell envelope of corynebacteria is similar to that of mycobacteria, consisting of a typical plasma membrane bilayer, a thick electron-dense layer (EDL), an electrontransparent layer (ETL) and an outer layer (OL). The electron density of the EDL makes it likely that it contains the cell wall peptidoglycan, which possesses charged groups able to bind metallic stains used in electron microscopy. The EDL is surrounded by a thin ETL which is traditionally considered to consist of mycolic residues, based on the transparency of this layer to electrons; indeed, the occurrence of eumycoloyl, nocardomycoloyl, or corynomycololyl residues covalently linked to the cell wall arabinogalactan of mycobacteria and related genera, on the one hand, and the effect of the removal of lipids from isolated mycobacterial cell walls, which causes the disappearance of the layer, on the other hand, support this interpretation. Surprisingly, however, this layer was seen in all corynebacterial species examined, including C. amycolatum, which is devoid of corynomycolates (Fig. 1); indeed, this observation could be explained by the replacement on the arabinogalactan of C. amycolatum of corynomycoloyl residues by normal-chain fatty acyl residues, i.e. $\mathrm{C}_{16-18}$. This hypothesis was ruled out by the analysis of the purified cell walls of the bacterium, where no fatty acyl substituent could be detected, indicating that the ETL was not synonymous with a lipid layer. Furthermore, the thickness of this layer in corynebacteria is comparable to that measured in mycobacteria $(6-7 \mathrm{~nm})$. Assuming a linearity between the thickness of the hydrocarbon portion and the number of carbon atoms, the theoretical length of the $\mathrm{C}_{50-60}$ main alkyl chain, the so-called meromycolate chain, of eumycoloyl residues is estimated to be $6.5 \mathrm{~nm}$ (see Daffé \& Draper, 1998) and that of corynomycoloyl residues $\left(\mathrm{C}_{16}\right)$ should be onethird of that observed in mycobacteria. Clearly, further studies are warranted to decipher the chemical nature of the ETL in corynebacteria and mycobacteria. The OL of the corynebacterial strains examined were heavily stained with ruthenium red, as previouly seen for mycobacteria (Rastogi et al., 1986) but in apparent conflict with a previous report (Rastogi et al., 1984). Although it is not clear what bacterial components react with the dye, it is evident that these are not acidic polysaccharides as previously claimed (Rastogi et al., 1984), primarily because the outermost carbohydrate constituents of corynebacteria (this study) and myco- bacteria (Ortalo-Magné et al., 1995; Lemassu et al., 1996) were found almost exclusively to be neutral substances.

Consistent with the phylogenetic relatedness between mycobacteria and corynebacteria is the observation that the main structural features of the major polysaccharides of the two genera were very similar. No gross structural difference was found between the non-covalently associated cell envelope polysaccharides, i.e. the $110 \mathrm{kDa}$ glucan, $13 \mathrm{kDa}$ arabinomanan and lipoglycans, characterized in this study and those published for mycobacteria (Lemassu \& Daffé, 1994; Lemassu et al., 1996; Ortalo-Magné et al., 1995; Hunter et al., 1986); in addition, low-molecular-mass glucan and arabinomannan, not previously described in mycobacteria, were identified in corynebacteria. The backbone of the major cell wall polysaccharide, arabinogalactan, was also found to be held in common between mycobacteria (Daffé et al., 1990,1993) and corynebacteria (Abou-Zeid et al., 1982; this study). In contrast to mycobacteria, however, while the mycobacterial arabinogalactans are almost exclusively composed of Ara and Gal residues (Daffé et al., 1993), significant amounts of Man and Glc residues may be found covalently linked to arabinan and/or galactan segments, a situation encountered in other actinomycetes such as rhodococci and nocardiae (Daffé et al., 1993). As in these latter genera, the glycosyllinkage composition of arabinogalactan in corynebacteria may vary according to the species examined.

Although they are Gram-positive bacteria, corynebacteria and closely related micro-organisms share with Gram-negative bacteria the property of possessing in their envelopes an outer barrier that is distinct from the plasma membrane. While this additional barrier in Gram-negative micro-organisms is a typical bilayer of phospholipid and lipopolysaccharide, in mycobacteria and corynebacteria the cell-wall-linked mycolates and corynomycolates certainly contribute to this barrier, since the disruption of genes that code for mycoloyltransferases causes a decrease in the amount of cell wallbound mycolates and corynomycolates, and affects the permeability of the envelope of the mutants (Jackson et al., 1999; Puech et al., 2000). This outer permeability barrier also includes non-covalently linked lipids which are probably arranged to form a bilayer with the corynomycoloyl residues, as proposed for mycobacteria (Minnikin 1982; Rastogi, 1991; Liu et al., 1995). As expected from these data, freeze-fractured samples of mycobacteria, corynebacteria and related genera showed that these organisms possess, in addition to the expected plasma membrane fracture, a major plane of weakness in their cell walls, close to the cell surface of mycobacteria (Chami et al., 1995; Benedetti et al., 1984). The present study extends this concept by showing that the various corynebacterial strains that are devoid of corynomycolates, i.e. C. amycolatum, exhibit only one fracture plane, which occurs in their plasma membrane, whereas the corynomycolate-containing strains exhibit a cell wall fracture plane, with the notable exception of the type strain of C. xerosis. Paradoxically, this strain 


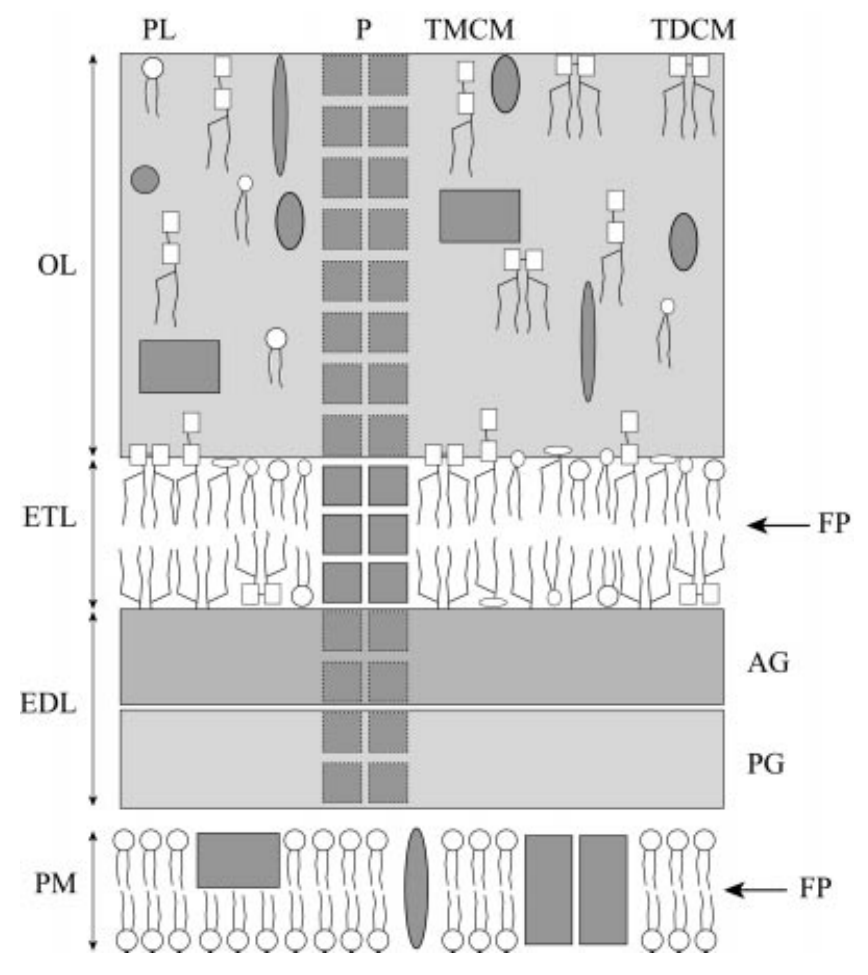

Fig. 7. A tentative model for the cell envelope of corynomycolate-containing corynebacteria, e.g. C. glutamicum. From the cytoplasmic to the external side of the bacteria the cell envelope is composed of a plasma membrane (PM), a complex wall that is seen in thin sections as an electron-dense layer (EDL) and an electron-transparent layer (ETL), and an outer layer (OL). The PM is a typical bilayer of proteins (dark rectangles and oval spots) and phospholipids ( $\mathrm{PL}$, empty oval symbols). The EDL consists of thick peptidoglycan (PG) covalently linked to the heteropolysaccharide arabinogalactan (AG); some of the arabinosyl termini of this polysaccharide are esterified by $\mathrm{C}_{32-36}$ corynomycolic acids (thin parallel bars). Because the amount of these fatty acids in most corynebacteria is not sufficient to cover the bacterial surface (see text), covalently bound corynomycoloyl residues are probably arranged to form with other non-covalently linked lipids, e.g. trehalose dicorynomycolates (TDCM, a pair of empty squares with two pairs of thin parallel bars), and trehalose monocorynomycolates (TMCM, a pair of empty squares with one pair of thin parallel bars), the inner leaflet of symmetric bilayer that represents a virtually outer barrier obstructing access of hydrophilic substances; the outer leaflet is composed of non-covalently linked lipids which assemble themselves into a monolayer. In addition, like that of Gram-negative bacteria, the cell envelope of corynebacteria contains proteins, including ones with pore-forming ability ( $P$, grey squares) which are present in all the cell envelope compartments, except the PM. In freeze-fractured and deep-etched preparations of most corynomycolate-containing strains the major fracture plane (FP) is seen within the cell wall, presumably located between the two leaflets of the outer membrane (arrow); in strains devoid of corynomycolates and porins, e.g. C. amycolatum, the FP occurs within the PM (arrow). The different non-covalently linked lipids are also present in the $\mathrm{OL}$, which consists primarily of polysaccharides and contains proteins.

possesses a relatively high content of covalently linked cell wall corynomycolates (Table 3) but most cells exhibit only a plasma membrane fracture plane, indi- cating that the corynomycolate content is not sufficient to explain the occurrence of the cell wall fracture plane. Furthermore, in most corynebacterial species examined, notably the csp1-inactivated mutant of C. glutamicum (CGL2022), the amount of covalently linked cell wall corynomycolates (Table 3 ) is less than the $0.085 \mu \mathrm{mol}$ of mycolic acids necessary for forming a monolayer which would cover the $230 \mathrm{~cm}^{2}$ bacterial cell surface area (calculated for $1 \mathrm{mg}$ of bacterial dry weight; see Nikaido et al., 1995). To reconcile this fact with the occurrence of the second fracture plane in the cell envelope of most of the corynomycolate-containing species, we reasoned that other non-covalently linked lipids, e.g. trehalose dicorynomycolate, may interact with the covalently bound cell wall corynomycolates to form a monolayer which would cover the bacterial cell surface area. This assumption was based first on the structural analogy between $\mathrm{C}_{32-36}$ corynomycolate-containing molecules, whose two $\mathrm{C}_{16-18}$ chains would be involved in hydrophobic interactions in a monolayer model, and $\mathrm{C}_{16-18^{-}}$ containing complex lipid compounds. In this respect, it has been shown that, like phospholipids, suspensions of synthetic trehalose dicorynomycolates exhibited welldefined transition phases and that these suspensions in a fluid state were clearly more active on mitochondria than in a gel state (Durand et al., 1979). Secondly, and more importantly, we showed that trehalose dicorynomycolates are capable of forming bilayers. Consequently, a quantification of lipid extracts from the various corynebacterial strains was undertaken (Table $3)$; this led to the demonstration that strains exhibiting a second fracture plane contained more extractable lipids than those lacking the cell wall fracture plane. Based on this observation, we speculate (Fig. 7) that in most corynebacteria, non-covalently linked lipid molecules are involved in the monolayer that is traditionally composed of mycolates. Thus, although the cell envelopes of corynebacteria and mycobacteria have several chemical and physical properties in common, the two organisms may be different in terms of the intimate arrangement of their constituents.

The existence in mycobacteria, corynebacteria and related genera of an outer membrane diffusion barrier poses a vital problem to the bacterial cell, i.e. to obtain a supply of nutrients; like those of Gram-negative bacteria, the cell envelopes of some members of the Mycobacterium genus and related genera contain specialized non-specific pore-forming proteins (porins) which certainly facilitate the passage of small hydrophilic molecules through their outer membranes (Kartmann et al., 1999; Lichtinger et al., 1998, 1999; Rieß et al., 1998; Mukhopadhyay et al., 1997; Trias et al., 1992; Trias \& Benz, 1994; Senaratne et al., 1998). To determine precisely the localization of these porins in the bacterial cell and their distribution in other members of the genus Corynebacterium, we investigated the occurrence of the low-molecular-mass porins recently characterized in C. glutamicum (Lichtinger et al., 1998) in different cell fractions of various corynebacterial strains. We demonstrated that functionally active low- 
molecular-mass porins occur in some corynebacterial species, e.g. C. diphtheriae and C. xerosis ATCC 7711, but not in all corynebacteria, e.g. C. amycolatum and the type strain of C.xerosis (ATCC 373). These peptides are found mainly in the cell wall fractions, as expected, but are also present in culture filtrates and the cell surfaces, but not in the plasma membranes, of the bacteria. It has to be noted that strains lacking porins, and virtually devoid of an outer permeability barrier, do not need these proteins for the uptake of nutrients since they present no obvious growth defect on complex media. Therefore, although strains of corynebacteria appear in numerical phenetic studies as clusters closely associated with each other, the present study clearly showed that, unlike mycobacteria, the genus Corynebacterium is heterogeneous in terms of both cell wall chemical composition and cell envelope organization.

\section{ACKNOWLEDGEMENTS}

The authors are grateful to Kristel Rouja, François Devesa, Laurent Thion and Debora Hodin (IPBS, Toulouse, France) and Oliver Knapp (Universität Würzburg, Germany) for their assistance, and to Thérèse Brando (IPBS, Toulouse) for providing the authentic samples of mycobacterial lipoarabinomannan and lipomannan. We also thank Dr Tadek GulikKrzywicki (CGM, Gif-sur-Yvette, France) and Professor Gilbert Lanéelle (IPBS, Toulouse, France) for helpful discussions. This work was partly supported by the Centre National de la Recherche Scientifique (CNRS, France) and the Ministère de l'Education Nationale, de la Recherche et de la Technologie (Programme de Recherche Fondamentale en Microbiologie et Maladies Infectieuses et Parasitaires).

\section{REFERENCES}

Abou-Zeid, C., Voiland, A., Michel, G. \& Cocito, C. (1982). Structure of the wall polysaccharide isolated from a group of corynebacteria. Eur J Biochem 128, 363-370.

Aggerbeck, L. \& Gulik-Krzywicki, T. (1986). Studies of lipoproteins by freeze-fracture and etching electron microscopy. Methods Enzymol 128, 457-472.

Barksdale, L. (1959). Lysogenic conversions in bacteria. Bacteriol Rev 23, 202-212.

Barksdale, L. (1970). Corynebacterium diphtheriae and its relatives. Bacteriol Rev 34, 378-422.

Barksdale, L. \& Kim, K.-S. (1977). Mycobacterium. Bacteriol Rev 41, 217-372.

Barreau, C., Bimet, F., Kiredjian, M., Rouillon, N. \& Bizet, C. (1993). Comparative chemotaxonomic studies of mycolic acid-free coryneform bacteria of human origin. J Clin Microbiol 31, 2085-2090.

Benedetti, E. L., Dunia, I., Ludosky, M. A., Man, N. V., Trach, D. D., Rastogi, N. \& David, H. L. (1984). Freeze-etching and freezefracture structural features of cell envelopes in mycobacteria and leprosy derived corynebacteria. Acta Leprol 95, 237-248.

Benz, R., Janko, K., Boos, W. \& Läuger, P. (1978). Formation of large, ion-permeable membrane channels by the matrix protein (porin) of Escherichia coli. Biochim Biophys Acta 511, 305-319.

Bligh, E. \& Dyer, W. J. (1959). Extraction des lipides. Can J Biochem Physiol 37, 88-97.

Chami, M., Bayan, N., Dedieu, J.-C., Leblon, G., Shechter, E. \& Gulik-Krzywicki, T. (1995). Organisation of the outer layers of the cell envelope of Corynebacterium glutamicum: a combined freeze-etch electron microscopy and biochemical study. Biol Cell 83, 219-229.

Christensen, H., Garton, N. J., Horobin, R. W., Minnikin, D. E. \& Barer, M. R. (1999). Lipid domains of mycobacteria studied with fluorescent molecular probes. Mol Microbiol 31, 1561-1572.

Collins, M. D., Goodfellow, M. \& Minnikin, D. E. (1982). A survey of the structures of mycolic acids in Corynebacterium and related taxa. J Gen Microbiol 128, 129-149.

Collins, M. D., Burton, R. A. \& Jones, D. (1988). Corynebacterium amycolatum sp. nov., a new mycolic acid-less Corynebacterium species from human skin. FEMS Microbiol Lett 49, 349-352.

Coyle, M. B. \& Lipsky, B. A. (1990). Coryneform bacteria in infectious diseases: clinical and laboratory aspects. Clin Microbiol Rev 3, 227-246.

Coyle, M. B., Leonard, R. B., Nowowiejski, D. K. \& Finn, D. J. (1993). Evidence of multiple taxa within commercially available reference strains of Corynebacterium xerosis. J Clin Microbiol 31, 1788-1793.

Daffé, M. \& Draper, P. (1998). The envelope layers of mycobacteria with reference to their pathogenicity. Adv Microb Physiol 39, 131-203.

Daffé, M., Lanéelle, M.-A., Asselineau, C., Lévy-Frébault, V. \& David, H. L. (1983). Intérêt taxonomique des acides gras des Mycobactéries: proposition d'une méthode d'analyse. Ann Microbiol 134B, 241-256.

Daffé, M., Brennan, P. J. \& McNeil, M. (1990). Predominant structural features of the cell wall arabinogalactan of Mycobacterium tuberculosis as revealed through characterization of oligoglycosyl alditol fragments by gas chromatography/mass spectrometry and by ${ }^{1} \mathrm{H}$ and ${ }^{13} \mathrm{C}$ NMR analyses. J Biol Chem 265, 6734-6743.

Daffé, M., McNeil, M. \& Brennan, P. J. (1993). Major structural features of the cell wall arabinogalactans of Mycobacterium, Rhodococcus and Nocardia. Carbohydr Res 249, 383-394.

Dittmer, J. C. F. \& Lester, R. L. (1964). A simple specific spray for the detection of phospholipids on thin layer chromatography. $J$ Lipid Res 5, 126-127.

Draper, P. (1982). The anatomy of Mycobacteria. In The Biology of the Mycobacteria, vol. 1, pp. 9-49. Edited by C. Ratledge \& J. L. Stanford. London: Academic Press.

Draper, P. (1998). The outer parts of the mycobacterial envelope as permeability barriers. Frontiers Biosci 3, d1253-d1261.

Dubnau, E., Chan, J., Raynaud, C., Mohan, V. P., Lanéelle, M.-A., Yu, K., Quémard, A., Smith, I. \& Daffé, M. (2000). Oxygenated mycolic acids are necessary for virulence of $M$. tuberculosis in mice. Mol Microbiol 36, 630-637.

Durand, E., Gillois, M., Tocanne, J.-F. \& Lanéelle, G. (1979). Property and activity of cord factor and related bacterial glycolipid toxins. Effects on mitochondrial oxidative phosphorylation related to organization of suspensions and to acyl chain structures. Eur J Biochem 94, 110-118.

Funke, G., Lawson, P. A., Bernard, K. A. \& Collins, M. D. (1996). Most Corynebacterium xerosis strains identified in the routine clinical laboratory correspond to Corynebacterium amycolatum. J Clin Microbiol 34, 1124-1128.

Funke, G., von Graevenitz, A., Clarridge, J. E., III \& Bernard, K. A. (1997). Clinical microbiology of coryneform bacteria. Clin Microbiol Rev 10, 125-159.

George, K. M., Yuan, Y., Sherman, D. R. \& Barry, C. E., III (1995). The biosynthesis of cyclopropanated mycolic acids in $\mathrm{Myco-}$ 
bacterium tuberculosis. Identification and functional analysis of cmas-2. J Biol Chem 270, 27292-27298.

Huchenq, A., Marquet, M., Welby, M., Montrozier, H., Goma, G. \& Lanéelle, G. (1984). Glutamate excretion triggering mechanism: a reinvestigation of the surfactant-induced modification of cell lipids. Ann Microbiol 135B, 53-67.

Hunter, S. W., Gaylord, H. \& Brennan, P. J. (1986). Structure and antigenicity of the phosphorylated lipopolysaccharide antigens from the leprosy and tubercle bacilli. J Biol Chem 261, 1234512351.

Jackson, M., Raynaud, C., Lanéelle, M.-A., Guilhot, C., LaurentWinter, C., Ensergueix, D., Gicquel, B. \& Daffé, M. (1999). Inactivation of the antigen $85 \mathrm{C}$ gene profoundly affects the mycolate content and alters the permeability of the Mycobacterium tuberculosis cell envelope. Mol Microbiol 31, 15731587.

Joliff, G., Mathieu, L., Hahn, V., Bayan, N., Duchiron, F., Renaud, M., Shechter, E. \& Leblon, G. (1992). Cloning and nucleotide sequence of the $\operatorname{csp} 1$ gene encoding PS1, one of the two major secreted proteins of Corynebacterium glutamicum: the deduced $\mathrm{N}$-terminal region of PS1 is similar to the Mycobacterium antigen 85 complex. Mol Microbiol 6, 2349-2362.

Kartmann, B., Stengler, S. \& Niederweis, M. (1999). Porins in the cell wall of Mycobacterium tuberculosis. J Bacteriol 181, 65436546.

Krämer, R. (1994). Secretion of amino acids by bacteria: physiology and mechanism. FEMS Microbiol Rev 13, 75-94.

Laemmli, U. K. (1970). Cleavage of structural proteins during the assembly of the head of bacteriophage T4. Nature 227, 680-685.

Lemassu, A. \& Daffé, M. (1994). Structural features of the exocellular polysaccharides of Mycobacterium tuberculosis. Biochem J 297, 351-357.

Lemassu, A., Ortalo-Magné, A., Bardou, F., Silve, G., Lanéelle, M.-A. \& Daffé, M. (1996). Extracellular and surface-exposed polysaccharides of non tuberculous mycobacteria. Microbiology 142, 1513-1520.

Leopold, K. \& Fisher, W. (1993). Molecular analysis of the lipoglycans of Mycobacterium tuberculosis. Anal Biochem 208, 57-84.

Lichtinger, T., Burkovski, A., Niederweis, M., Krämer, R. \& Benz, R. (1998). Biochemical and biophysical characterization of the cell wall porin of Corynebacterium glutamicum: the channel is formed by a low molecular mass polypeptide. Biochemistry 37, 15024-15032.

Lichtinger, T., Heym, B., Maier, E., Eichner, H., Cole, S. T. \& Benz, R. (1999). Evidence for a small anion-selective channel in the cell wall of Mycobacterium bovis BCG besides a wide cation-selective pore. FEBS Lett 454, 349-355.

Liu, J., Rosenberg, E. Y. \& Nikaido, H. (1995). Fluidity of the lipid domain of cell wall from Mycobacterium chelonae. Proc Natl Acad Sci U S A 92, 11254-11258.

Liu, J., Barry, C. E., III, Besra, G. S. \& Nikaido, H. (1996). Mycolic acid structure determines the fluidity of the mycobacterial cell wall. J Biol Chem 271, 29545-29551.

Lounatmaa, K. \& Brander, E. (1989). Crystalline cell surface layer of Mycobacterium bovis BCG. J Bacteriol 171, 5756-5758.

Marienfeld, S., Uhlemann, E.-M., Krämer, R. \& Burkovski, A. (1997). Ultrastructure of the Corynebacterium glutamicum cell wall. Antonie Leeuwenhoek 72, 291-297.

Minnikin, D. E. (1982). Lipids: complex lipids, their chemistry, biosynthesis and roles. In The Biology of the Mycobacteria, vol.
1, pp. 95-184. Edited by C. Ratledge \& J. L. Stanford. London: Academic Press.

Minnikin, D. E. \& Goodfellow, M. (1980). Lipid composition in the classification and identification of acid-fast bacteria. In Microbiological Classification and Identification, pp. 189-239. Edited by M. Goodfellow \& R. G. Board. London: Academic Press.

Minnikin, D. E. \& O’Donnell, A. G. (1984). Actinomycete envelope lipid and peptidoglycan composition. In The Biology of Actinomycetes, pp. 337-388. Edited by M. Goodfellow, M. Mordarski \& S. T. Williams. London: Academic Press.

Minnikin, D. E., Goodfellow, M. \& Collins, M. D. (1978). Lipid composition in the classification and identification of coryneform and related taxa. In Coryneform Bacteria, pp. 85-160. Edited by I. J. Bousfield \& A. G. Callely. London: Academic Press.

Mukhopadhyay, S., Basu, D. \& Chakrabarti, P. (1997). Characterization of a porin from Mycobacterium smegmatis. J Bacteriol 179, 6205-6207.

Nikaido, H., Kim, S.-H. \& Rosenberg, E. Y. (1995). Physical organization of lipids in the cell wall of Mycobacterium chelonae. Mol Microbiol 8, 1025-1030.

Ortalo-Magné, A., Dupont, M.-A., Lemassu, A., Andersen, A. B., Gounon, P. \& Daffé, M. (1995). Molecular composition of the outermost capsular material of the tubercle bacillus. Microbiology 141, 1609-1620.

Ortalo-Magné, A., Lemassu, A., Lanéelle, M.-A., Bardou, F., Silve, G., Gounon, P., Marchal, G. \& Daffé, M. (1996). Identification of the surface-exposed lipids on the cell envelopes of Mycobacterium tuberculosis and other mycobacterial species. J Bacteriol 178, 456-461.

Paul, T. R. \& Beveridge, T. J. (1992). Re-evaluation of envelope profiles and cytoplasmic ultrastructure of mycobacteria processed by conventional embedding and freeze-substitution protocols. $J$ Bacteriol 174, 6508-6517.

Peyret, J.-L., Bayan, N., Joliff, G., Gulik-Krzywicki, T., Mathieu, L., Shechter, E. \& Leblon, G. (1993). Characterization of the $c s p B$ gene encoding PS2, an ordered surface-layer protein in Corynebacterium glutamicum. Mol Microbiol 9, 97-109.

Puech, V., Bayan, N., Salim, K., Leblon, G. \& Daffé, M. (2000). Characterization of the in vivo acceptors of the mycoloyl residues transferred by the corynebacterial PS1 and the related mycobacterial antigens 85. Mol Microbiol 35, 1026-1041.

Rastogi, N. (1991). Recent observations concerning structure and function relationships in the mycobacterial cell envelope: elaboration of a model in terms of mycobacterial pathogenicity, virulence and drug-resistance. Res Microbiol 142, 464-476.

Rastogi, N., Frehel, C. \& David, H. L. (1984). Cell envelope architectures of leprosy-derived corynebacteria, Mycobacterium leprae, and related organisms: a comparative study. Curr Microbiol 11, 23-30.

Rastogi, N., Fréhel, C. \& David, H. L. (1986). Triple-layered structure of mycobacterial cell wall: evidence for the existence of a polysaccharide-rich outer layer in 18 mycobacterial species. Curr Microbiol 13, 237-242.

Raynaud, C., Etienne, G., Peyron, P., Lanéelle, M. A. \& Daffé, M. (1998). Delineation of extracellular enzymic activities potentially involved in the pathogenicity of Mycobacterium tuberculosis. Microbiology 144, 577-587.

Rieß, F. G., Lichtinger, T., Cseh, R., Yassin, A. F., Schaal, K. P. \& Benz, R. (1998). The cell wall porin of Nocardia farcinica: biochemical identification of the channel-forming protein and biophysical characterization of the channel properties. Mol Microbiol 29, 139-150. 
Salim, K., Haedens, V., Content, J., Leblon, G. \& Huygen, K. (1997). Heterologous expression of the Mycobacterium tuberculosis gene encoding antigen 85A in Corynebacterium glutamicum. Appl Environ Microbiol 63, 4392-4400.

Senaratne, R. H., Mobasheri, H., Papavinasasundaram, K. G., Jenner, P., Lea, E. J. A. \& Draper, P. (1998). Expression of gene for a porin-like protein of the OmpA family from Mycobacterium tuberculosis H37Rv. J Bacteriol 180, 3541-3547.

Soual-Hoebeke, E., de Sousa-D'Auria, C., Chami, M., Baucher, M.-F., Guyonvarch, A., Bayan, N., Salim, K. \& Leblon, G. (1999). S-layer protein production by Corynebacterium strains is dependent on the carbon source. Microbiology 145, 3399-3408.

Sutcliffe, I. C. (1995). Identification of a lipoarabinomannan-like lipoglycan in Corynebacterium matruchotii. Arch Oral Biol 40, 1119-1124.

Sutcliffe, I. C. (1997). Macroamphiphilic cell envelope components of Rhodococcus equi and closely related bacteria. Vet Microbiol 56, 287-299.

Sweeley, C. C., Bentley, R., Makita, M. \& Wells, W. W. (1963). Gas-liquid chromatography of trimethylsilyl derivatives of sugars and related substances. J Am Chem Soc 85, 2497-2507.

Takeo, K., Kimura, K., Kuze, F., Nakai, E., Nonaka, T. \& Nishiura,
M. (1984). Freeze-fracture observations on the cell walls and peribacillary substances of various mycobacteria. J Gen Microbiol 130, 1151-1159.

Towbin, H., Staehelin, T. \& Gordon, J. (1979). Electrophoretic transfer of proteins from polyacrylamide gels to nitrocellulose sheets: procedure and some applications. Proc Natl Acad US A 76, 4350-4354.

Trias, J. \& Benz, R. (1994). Permeability of the cell wall of Mycobacterium smegmatis. Mol Microbiol 14, 283-290.

Trias, J., Jarlier, V. \& Benz, R. (1992). Porins in the cell wall of mycobacteria. Science 258, 1479-1481.

Trieu-Cuot, P. \& Courvalin, P. (1983). Nucleotide sequence of the Streptococcus faecalis plasmid gene encoding the $3^{\prime} 5^{\prime}$-aminoglycoside phosphotransferase type III. Gene 23, 331-341.

Welby-Gieusse, M., Lanéelle, M.-A. \& Asselineau, J. (1970). Structure des acides corynomycoliques de Corynebacterium hofmanii et leur implication biogénétique. Eur J Biochem 13, 164-167.

Received 30 October 2000; revised 30 January 2001; accepted 1 February 2001. 